\title{
Genetic Dysmyelination Alters the Molecular Architecture of the Nodal Region
}

\author{
Edgardo J. Arroyo, ${ }^{1}$ Theodore Xu, ${ }^{1}$ Judith Grinspan, ${ }^{2}$ Stephen Lambert, ${ }^{3}$ S. Rock Levinson, ${ }^{4}$ \\ Peter J. Brophy, ${ }^{5}$ Elior Peles, ${ }^{6}$ and Steven S. Scherer ${ }^{1}$ \\ ${ }^{1}$ Department of Neurology, The University of Pennsylvania Medical Center and 2Division of Neurology Research, \\ Children's Hospital of Philadelphia, Philadelphia, Pennsylvania 19104-6077, 3Program in Neuroscience, University of \\ Massachusetts Medical Center, Worcester, Massachusetts 01605, ${ }^{4}$ Department of Physiology, University of Colorado \\ Health Science Center, Denver, Colorado 80262, ${ }^{5}$ Department of Preclinical Veterinary Sciences, University of Edinburgh, \\ Summerhall, Edinburgh EH9 1QH, United Kingdom, and ${ }^{6}$ Department of Molecular Cell Biology, Weizmann Institute of \\ Science, 76100 Rehovot, Israel
}

\begin{abstract}
We have examined the molecular organization of axons in the spinal cords of myelin-deficient $(m d)$ rats, which have profound CNS dysmyelination associated with oligodendrocyte cell death. Although myelin sheaths are rare, most large axons are at least partially surrounded by oligodendrocyte processes. At postnatal day 7 (P7), almost all node-like clusters of voltagegated $\mathrm{Na}^{+}$channels and ankyrin ${ }_{\mathrm{G}}$ are adjacent to axonal segments ensheathed by oligodendrocytes, but at P21, many node-like clusters are found in axonal segments that lack oligodendrocyte ensheathment. In P21 wild-type (WT) rats, the voltage-gated $\mathrm{Na}^{+}$channels $\mathrm{Na}_{v} 1.2, \mathrm{Na}_{v} 1.6$, and $\mathrm{Na}_{v} 1.8$, are found in different subpopulations of myelinated axons, and $m d$ rats have a similar distribution. The known molecular components of paranodes - contactin, Caspr, and neurofascin 155are not clustered in md spinal cords, and no septate-like junc-
\end{abstract}

tions between oligodendrocyte processes and axons are found by electron microscopy. Furthermore, Kv1.1 and $\mathrm{Kv} 1.2 \mathrm{~K}^{+}$ channels are not spatially segregated from the node-like clusters of $\mathrm{Na}^{+}$channels in $m d$ rats, in contrast to their WT littermates. These results suggest the following: node-like clusters of voltage-gated $\mathrm{Na}^{+}$channels and ankyrin ${ }_{\mathrm{G}}$ form adjacent to ensheathed axonal segments even in the absence of a myelin sheath; these clusters persist after oligodendrocyte cell death; dysmyelination does not alter the expression of different nodal of voltage-gated $\mathrm{Na}^{+}$channels; the absence of paranodes results in the mislocalization of neurofascin155, contactin, and Caspr, and the aberrant localization of Kv1.1 and Kv1.2.

Key words: myelin; oligodendrocytes; mutant; septate junctions; axon-glia interactions; proteolipid protein
The molecular organization of the axonal membrane is highly related to that of its myelin sheaths (Arroyo and Scherer, 2000; Peles and Salzer, 2000; Rasband and Shrager, 2000). In both the CNS and PNS, the nodal membrane contains high concentrations of voltage-gated $\mathrm{Na}^{+}$channels, which are linked to the spectrin cytoskeleton by ankyrin $\mathrm{G}_{\mathrm{G}}$. The paranodal region is distinguished by septate-like junctions that link the axonal membrane to the spiral of glial endfeet. Contactin and contactin-associated protein (Caspr; also known as paranodin) are localized to the paranodal axonal membrane. An alternatively spliced isoform of neurofascin, neurofascin $155 \mathrm{kDa}$ (NF155), is localized on the membrane of the glial endfeet apposing the paranodal axonal membrane, so that contactin, Caspr, and NF155 are likely to be components of septate-like junctions. The juxtaparanodal axonal membrane contains high levels of the Shaker-type $\mathrm{K}^{+}$channels, Kv1.1 and $\mathrm{Kv} 1.2$, their associated $\beta$ subunit, $\mathrm{Kv} \beta 2$, and Caspr2 (an additional member of the Caspr family). Kv1.1, Kv1.2, and Caspr2 all

\footnotetext{
Received Nov. 9, 2001; revised Nov. 9, 2001; accepted Dec. 12, 2001.
}

This work was supported by the The Charcot-Marie-Tooth Association (E.J.A.), National Institutes of Health Grants NS08075, NS37100, and NS34528 (S.S.S.) and NS36637 (S.L.), and National Multiple Sclerosis Society Grant RG-3102 (E.P.). Ori Peles is Incumbent of the Madeleine Haas Russell Career Development Chair. We thank Drs. Udo Bartsch, Jeff Bronstein, Virginia Lee, Jim Salzer, Jim Trimmer, Soichiro Tsukita, and Steve Waxman for their generous gifts of antibodies.

Correspondence should be addressed to Dr. Steven S. Scherer, 460 Stemmler Hall, 36th Street and Hamilton Walk, The University of Pennsylvania Medical Center, Philadelphia, PA 19104-6077. E-mail: sscherer@mail.med.upenn.edu.

Copyright (C) 2002 Society for Neuroscience $0270-6474 / 02 / 221726-12 \$ 15.00 / 0$ have PSD-95/Dlg/ZO-1 (PDZ)-binding domains at their intracellular $\mathrm{C}$ terminals and are likely linked to a PDZ protein, perhaps PSD95. An isoform of band 4.1 protein, band 4.1B, may link the glycophorin domains of Caspr and Caspr2 to the spectrin cytoskeleton.

A number of inherited dysmyelinating or demyelinating diseases that affect the PNS and/or the CNS that have been linked to mutations in genes that are expressed in the myelinating cells themselves. In humans and mice, different mutations of the proteolipoprotein gene ( $P L P / P l p)$ cause a range of phenotypes (Nave and Boespflug-Tanguy, 1996). Although these inherited dysmyelination-demyelinating diseases are caused by cell autonomous defects in the myelinating glial cells, nonautonomous damage to axons has been increasingly implicated as a crucial aspect of these diseases (Griffiths et al., 1998). How demyelination leads to axonal loss is not known, but the reorganization of the axonal membrane is the earliest known alteration. This was first observed for voltagegated $\mathrm{Na}^{+}$channels: nodal clusters are lost after demyelination, but reappear after remyelination (Dugandzija-Novakovic et al., 1995; Novakovic et al., 1996). Similarly, juxtaparanodal Kv1.1 and Kv1.2 channels disperse after demyelination and reorganize with remyelination (Rasband et al., 1998). In inherited dysmyelinatingdemyelinating diseases, the sequelae of demyelination and remyelination probably coexist even on the same myelinated fiber, resulting in a complex pathological picture. In this paper, we have investigated the organization of the axonal membrane in myelin- 


\begin{tabular}{|c|c|c|}
\hline Antibody & Dilution & Source/reference \\
\hline $\mathrm{Rb} \alpha$ pan $\mathrm{Na}^{+}$channels & $1: 500$ & Vabnick et al., 1997 \\
\hline $\mathrm{Rb} \alpha \mathrm{Na}_{\mathrm{v}} 1.2$ & $1: 100$ & Caldwell et al., 2000 \\
\hline $\mathrm{Rb} \alpha \mathrm{Na}_{\mathrm{v}} 1.6$ & $1: 100$ & Caldwell et al., 2000 \\
\hline $\mathrm{Rb} \alpha \mathrm{Na}_{\mathrm{v}} 1.7$ & $1: 100$ & Caldwell et al., 2000 \\
\hline $\mathrm{Rb} \alpha \mathrm{Na}_{\mathrm{v}} 1.8$ & $1: 100$ & Caldwell et al., 2000 \\
\hline $\mathrm{Rb} \alpha \mathrm{Na}_{\mathrm{v}} 1.9$ & $1: 100$ & Fjell et al., 2000 \\
\hline $\mathrm{Rb} \alpha \operatorname{ankyrin}_{\mathrm{G}}$ & $1: 100$ & Lambert et al., 1997 \\
\hline $\mathrm{Rb} \alpha \mathrm{Kv} 1.1$ & $1: 200$ & Alomone Labs, Jerusalem, Israel \\
\hline $\mathrm{Rb} \alpha \mathrm{Kv} 1.2$ & $1: 100$ & Alomone Labs \\
\hline $\mathrm{Rb} \alpha$ contactin & $1: 100$ & Rios et al., 2000 \\
\hline $\mathrm{Rb} \alpha \mathrm{Caspr}$ & $1: 500$ & Peles et al., 1997 \\
\hline $\mathrm{Rb} \alpha$ Caspr2 & $1: 50$ & Poliak et al., 1999 \\
\hline $\mathrm{Rb} \alpha$ neurofascin $155 \mathrm{kDa}$ & $1: 750$ & Tait et al., 2000 \\
\hline $\mathrm{Rb} \alpha$ rat $\mathrm{MAG}$ & $1: 300$ & Pedraza et al., 1990 \\
\hline $\mathrm{Rb} \alpha$ claudin -11 & $1: 500$ & Morita et al., 1999 \\
\hline $\mathrm{Rb} \alpha$ OSP & $1: 500$ & Bronstein et al., 2000 \\
\hline $\mathrm{Rb} \alpha \mathrm{NG} 2$ & $1: 200$ & Chemicon, Temecula, CA \\
\hline $\mathrm{M} \alpha$ pan $\mathrm{Na}^{+}$channels & $1: 50$ & Sigma \\
\hline $\mathrm{M} \alpha \operatorname{ankyrin}_{\mathrm{G}}$ & $1: 100$ & Zymed, San Francisco, CA \\
\hline $\mathrm{M} \alpha$ tenascin-R (619) & $1: 2$ & Weber et al., 1999 \\
\hline $\mathrm{M} \alpha \mathrm{Kv} 1.1$ & $1: 50$ & Upstate Biotechnology, Lake Placid, NY \\
\hline $\mathrm{M} \alpha \mathrm{Kv} 1.2$ & $1: 50$ & Upstate Biotechnology \\
\hline $\mathrm{M} \alpha$ rat MAG (513) & $1: 100$ & Boehringer Mannheim, Indianapolis, IN \\
\hline M $\alpha$ Caspr & $1: 50$ & Poliak et al., 1999 \\
\hline M $\alpha$ Caspr & $1: 50$ & Rasband and Trimmer, 2001b \\
\hline M $\alpha$ MBP (\#1849) & $1: 50$ & Serotec, Oxford, UK \\
\hline M $\alpha$ MBP (SMI 84) & $1: 50$ & Sternberger Monoclonals, Lutherville, MD \\
\hline M $\alpha$ NFM (RMO108) & $1: 10$ & Lee et al., 1982 \\
\hline RIP (M monoclonal) & $1: 10$ & Developmental Studies Hybridoma Bank, University of Iowa, Iowa City, IA \\
\hline rat $\alpha \mathrm{NFH}(\mathrm{Ta} 51)$ & $1: 10$ & Lee et al., 1982, 1987 \\
\hline $\mathrm{RPTP} \beta$-hFc fusion protein & $1: 2$ & Peles et al., 1995 \\
\hline FITC-cholera toxin & $1: 500$ & Sigma \\
\hline
\end{tabular}

Rb, Rabbit; M, mouse.

deficient $(m d)$ rats, which have a severe dysmyelinating disease associated with oligodendrocyte cell death (Gow et al., 1998; Grinspan et al., 1998; Lipsitz et al., 1998). Although few large CNS axons are myelinated, they are ensheathed by oligodendrocyte processes. Node-like clusters of $\mathrm{Na}^{+}$channels and ankyrin ${ }_{\mathrm{G}}$ develop at the edges of oligodendrocyte processes, but are subsequently found in regions devoid of oligodendrocytes. Ensheathed and even myelinated axons do not have molecular or structural specializations at paranodes, and Kv1.1 and Kv1.2 channels abut the node-like clusters of $\mathrm{Na}^{+}$channels and ankyrin $_{\mathrm{G}}$.

\section{MATERIALS AND METHODS}

Animals. Male $m d$ rats and their wild-type (WT) littermates were obtained from a colony at the University of Pennsylvania. Postnatal day 14 (P14) and P21 rats have an obvious tremor and gait difficulties; P7 rats were genotyped by PCR as described previously (Grinspan et al., 1998).

Immunostaining. P21 $m d$ rats and their WT male littermates were overdosed with pentobarbitol, then perfused with freshly prepared $4 \%$ paraformaldehyde in $0.1 \mathrm{M}$ phosphate buffer (PB), $\mathrm{pH}$ 7.4. The spinal cords were removed and fixed for a total of $30 \mathrm{~min}$ in the same fixative, rinsed in PB, and infiltrated in $20 \%$ sucrose $\mathrm{PB}$ overnight before embedding. Ten-micrometer-thick cryostat sections were thaw-mounted on SuperFrost Plus glass slides (Fisher Scientific, Pittsburgh, PA) and stored at $-20^{\circ} \mathrm{C}$. Sections were post-fixed and permeabilized by immersion in $-20^{\circ} \mathrm{C}$ acetone for $10 \mathrm{~min}$, blocked at room temperature for at least $1 \mathrm{hr}$ in 5\% fish skin gelatin containing $0.5 \%$ Triton X-100 in PBS, and incubated $24-48 \mathrm{hr}$ at $4^{\circ} \mathrm{C}$ with various combinations of primary antibodies (Table 1) diluted in blocking solution. After incubating with the primary antibodies, the slides were washed, incubated with the appropriate fluorescein-, rhodamine-, and cyanine 5-conjugated donkey cross-affinity-purified secondary antibodies (diluted 1:200; Jackson ImmunoResearch Laboratories, West Grove, PA), and mounted with Vectashield (Vector Laboratories, Burlingame, CA). The slides were examined by epifluorescence with tetramethylrhodamine isothiocyanate (TRITC) and fluorescein isothiocyanate (FITC) optics on a Leica (Nussloch, Germany) DMR light microscope and photographed with a Hamamatsu (Tokyo, Japan) digital camera or with a Leica TCS laser-scanning confocal microscope followed by image manipulation with Adobe Photoshop and Canvas.

To demonstrate the specificity of the $\mathrm{Na}_{\mathrm{v}} 1.2, \mathrm{Na}_{\mathrm{v}} 1.6$, and $\mathrm{Na}_{\mathrm{v}} 1.8$ antisera, a "blocking" experiment was performed. One microliter of each rabbit antiserum was mixed with $5 \mu \mathrm{l}$ of peptide (stock concentration 1 $\mu \mathrm{g} / \mu \mathrm{l})$ against which it was raised and incubated overnight at $4^{\circ} \mathrm{C}$. An equal amount of each antiserum was also treated in a similar manner, substituting PBS for the blocking peptide solution. The next morning, a pan- $\mathrm{Na}^{+}$monoclonal antibody was added to each tube, and the contents of the "blocked" and "unblocked" tubes were used to label slides of P21 $\mathrm{WT}$ and $m d$ spinal cord as described above.

Quantitiative analysis. To determine whether the number of node-like clusters was higher in $m d$ spinal cords, we embedded the cervical spinal cords from three P21 $m d$ rats and three age-matched male WT littermates in the same block. Ten-micrometer-thick frozen sections were double labeled with the rabbit antiserum against $\mathrm{Na}_{\mathrm{v}} 1.6$ and the pan $\mathrm{Na}^{+}$ channel mouse monoclonal antibody. A $130 \mu \mathrm{m}^{2}$ area of the ventral funiculus nearest to the midline was selected because this region contains many of the largest myelinated fibers in the spinal cord. We reasoned that examining large myelinated fibers would more easily reveal an increase in 

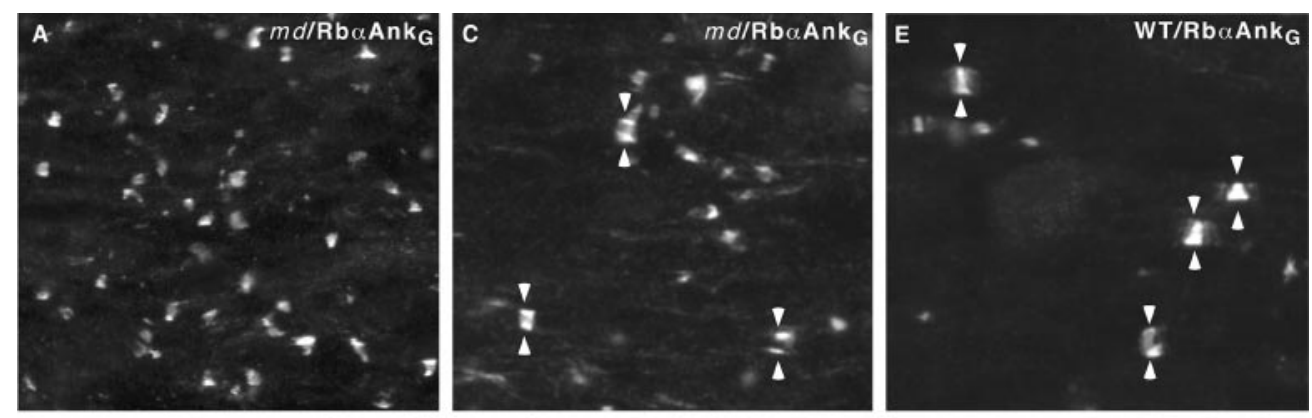
These images were taken from longitudinal sections of the ventral funiculus from $\mathrm{P} 21$ md $(A-D)$ or WT $(E, F)$ spinal cords, immunostained with a rabbit antiserum against ankyrin $_{\mathrm{G}}(A, C, E$; TRITC) and a monoclonal antibody against voltage-gated $\mathrm{Na}^{+}$channels $(B$; FITC) or tenascin-R ( $D, F$; FITC). Note that node-like clusters of colocalize with voltage-gated $\mathrm{Na}^{+}$channels and tenascin-R. The pairs of arrowheads mark the some of the node-like clusters in $C-F$. Scale bars, $10 \mu \mathrm{m}$.

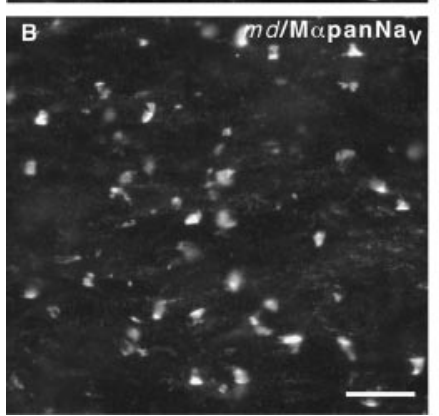

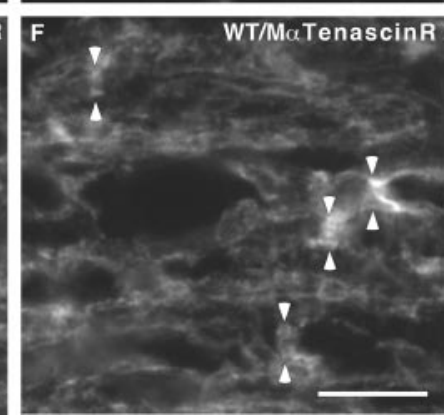

the number of node-like clusters in $m d$ rats. The number of node-like clusters were compared by Student's $t$ test using Microsoft Excel (mean $\pm \mathrm{SEM})$. To determine whether the proportion of $\mathrm{Na}_{\mathrm{v}}$ 1.6-positive clusters was different in the ventral funiculi of $m d$ spinal cords compared with P21 WT littermates, we enlarged nonoverlapping parts of the above digital images. By simultaneously comparing the $\mathrm{Na}_{\mathrm{v}} 1.6$ (TRITC) and the pan- $\mathrm{Na}^{+}$channel (FITC) images on the computer screen, we determined whether each pan- $\mathrm{Na}^{+}$channel cluster was $\mathrm{Na}_{\mathrm{v}}$ 1.6-positive. These data were compared by ANOVA test using Microsoft Excel.

To determine how many node-like clusters were related to myelin sheaths during development, we immunostained longitudinal sections of the ventral funiculus from the cervical cord from P7 (four $m d$ rats and four WT), P14 (two $m d$ and two WT), and P21 rats (two $m d$ and two WT) with the pan $\mathrm{Na}^{+}$channel monoclonal antibody (to label nodes) and a rabbit antiserum against MAG (to label ensheathed axonal segments). Sections were examined by epifluorescence as described above, and $40 \times$ digital images of the ventral funiculus were made for each animal. All the nodes in each image were counted and classified into one of three different categories: (1) naked clusters: node-like clusters of $\mathrm{Na}^{+}$ channels that were not flanked by MAG-positive ensheathed axonal segments; (2) heminodes: node-like clusters that were flanked on only side one by MAG-positive axonal segments; or (3) nodes: $\mathrm{Na}^{+}$channels that are flanked on both sides by MAG-positive axonal segments. The percentage of nodes was calculated at each age; ANOVA statistical analyses were used to compare the samples.

Electron microscopy. P21 md and WT male littermates were perfused with $0.9 \% \mathrm{NaCl}$ followed by $3 \%$ glutaraldehyde in PB. The cervical spinal cords were removed, cut into $2-3 \mathrm{~mm}$ wide segments, fixed overnight at $4^{\circ} \mathrm{C}$ in the same fixative, washed in $\mathrm{PB}$, osmicated in $1 \% \mathrm{OsO}_{4}$ for $1 \mathrm{hr}$ at room temperature, then dehydrated in graded ethanols, infiltrated with propylene oxide followed by Epon, and polymerized at $60^{\circ} \mathrm{C}$. Semithin sections were stained with toluidine blue; thin sections were stained with lead citrate and photographed with a Zeiss EM10 electron microscope. Electron micrographs were printed and scanned; these images were imported into Adobe Photoshop and assembled.

Immunoblot analysis. To determine whether the levels of axonal proteins were altered in $m d$ rats, we made protein homogenates from spinal cords (stripped of dura and rootlets) and sciatic nerves dissected from P21 md rats and their male WT littermates. Samples were immersed in liquid nitrogen, pulverized were a mortar and pestle on dry ice, and resuspended in ice-cold $50 \mathrm{~mm}$ Tris, $\mathrm{pH} 7.0,1 \% \mathrm{SDS}$, and $0.017 \mathrm{mg} / \mathrm{ml}$ phenylmethylsulfonyl fluoride (Sigma, St. Louis, MO), followed by a brief sonication on ice with a desmembrator (Fisher Scientific). Protein concentrations were determined using the Bio-Rad kit (Bio-Rad, Hercules, CA) according to manufacturer's instructions. For each sample, $\sim 100 \mu \mathrm{g}$ of protein lysate was loaded onto a 5\% SDS-polyacrylamide gel, electrophoresed, and transferred to nitrocellulose (for $\mathrm{Na}_{\mathrm{V}} 1.2, \mathrm{Na}_{\mathrm{V}} 1.6$, and $\mathrm{Na}_{\mathrm{V}} 1.8$ ) or Immobilon-polyvinylidene fluoride (Millipore, Bedford, MA; for contactin and Caspr) membrane over $1 \mathrm{hr}$, using a semidry transfer unit (Fisher Scientific). The blots were blocked (5\% powdered skim milk and $0.5 \%$ Tween 20 in Tris-buffered saline) overnight at $4^{\circ} \mathrm{C}$ and incubated for $24 \mathrm{hr}$ at $4^{\circ} \mathrm{C}$ in blocking buffer with rabbit antisera against $\mathrm{Na}_{\mathrm{V}} 1.2$ (1:1000), $\mathrm{Na}_{\mathrm{V}} 1.6$ (1:1000), $\mathrm{Na}_{\mathrm{V}} 1.8$ (1:1000), contactin (1:5000), or Caspr (1:5000). After washing in blocking solution, the blots were incubated in peroxidase-coupled secondary antibodies against rabbit (Jackson ImmunoResearch; diluted 1:10,000) for $1 \mathrm{hr}$ at room temperature (RT). After washing in blocking solution and Tris-buffered saline containing $0.5 \%$ Tween 20 , blots were visualized by enhanced chemiluminescence (Amersham, Arlington Heights, IL) according to the manufacturer's protocols. To visualize GAPDH, the blots were first washed in blocking buffer with $0.01 \%$ sodium azide and subsequently probed with a mouse monoclonal antibody against GAPDH $(1: 10,000)$ followed by washing in blocking solution. The blots were incubated in peroxidase-coupled secondary antibodies against mouse (Jackson ImmunoResearch; diluted 1:10,000) for $1 \mathrm{hr}$ at RT and visualized by enhanced chemiluminescence.

\section{RESULTS}

\section{Node-like clusters of $\mathrm{Na}^{+}$channels and ankyrin ${ }_{\mathrm{G}}$ in $\mathbf{m d}$ spinal cord}

To determine the localization of voltage-gated $\mathrm{Na}^{+}$channels in $m d$ rats, we immunostained sections with either a mouse monoclonal antibody or a rabbit antiserum that both recognize the same conserved peptide sequence common to all type 1 channels (Goldin, 1999). We embedded spinal cords of P21 $m d$ rats and their WT littermates to obtain longitudinal sections of the ventral funiculus, which contains the largest axons. As shown in Figures $1,2,3,7$, and 8 , there were node-like clusters of $\mathrm{Na}^{+}$channels in ventral funiculus of both WT and $m d$ rats: the clusters were thin ( $\sim 1 \mu \mathrm{m}$ in width) and perpendicular to the axons. In transverse sections of $m d$ spinal cord, these node-like clusters were often crescent-shaped rather than complete circles as in WT spinal cords (Fig. 3A-F), indicating that many do not surround the entire circumference of the axonal membrane.

To determine whether these node-like clusters colocalized with other molecular components of nodes, we double-labeled sections with pan- $\mathrm{Na}^{+}$channel antibodies (with either the mouse monoclonal antibody or the rabbit antiserum) and ankyrin $_{\mathrm{G}}$ (either a rabbit antiserum or a mouse monoclonal antibody; the rabbit 

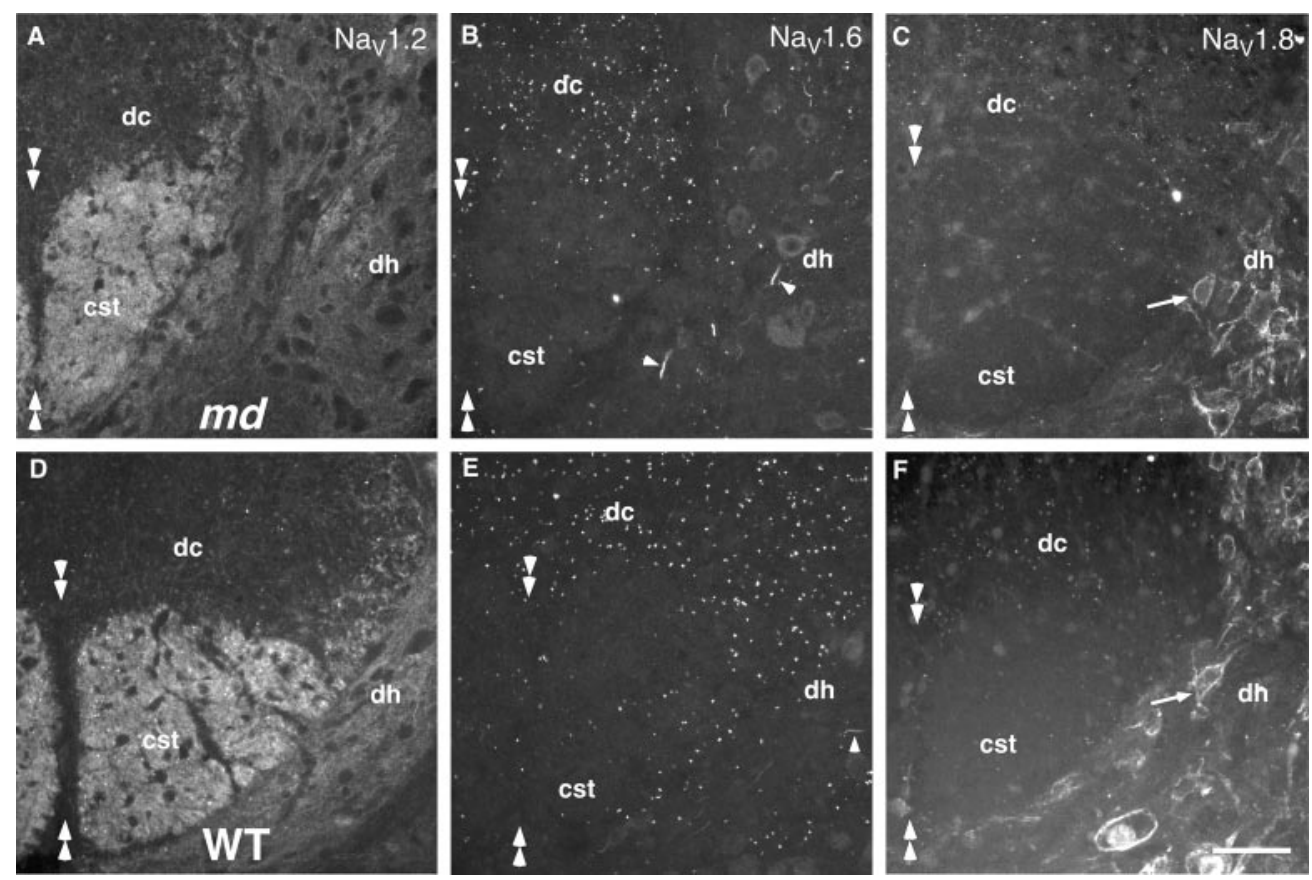

Figure 2. Similar localization of voltage-gated $\mathrm{Na}^{+}$channels in P21 md and WT spinal cords. These are images from transverse sections of the cervical spinal cord of P21 md and WT rats, immunostained for $\mathrm{Na}_{\mathrm{v}} 1.2, \mathrm{Na}_{\mathrm{v}} 1.6$, and $\mathrm{Na}_{\mathrm{v}} 1.8$. The midline is indicated by pairs of double arrowheads. There is diffuse $\mathrm{Na}_{\mathrm{v}} 1.2$ staining in the corticospinal tract (cst) and the adjacent gray matter of the dorsal horn $(d h) ; \mathrm{Na}_{\mathrm{v}} 1.8$ staining is mainly found in the membrane of neuronal cell bodies (arrowheads); $\mathrm{Na}_{\mathrm{v}} 1.6$ staining is found in the majority of nodes and initial segments (arrows). A few myelinated fibers in the dorsal columns $(d c)$ have $\mathrm{Na}_{\mathrm{v}} 1.2$ and $\mathrm{Na}_{\mathrm{v}} 1.8$ staining. The overall distribution of these $\mathrm{Na}^{+}$channels is not altered in $m d$ rats. Scale bar, $50 \mu \mathrm{m}$. antiserum was more reliable). Both combinations showed that $\mathrm{Na}^{+}$channels and ankyrin ${ }_{\mathrm{G}}$ were colocalized at nodes both in P21 md (Fig. 1 $A, B$ ) and in their WT littermates (data not shown). We also double-labeled sections for ankyrin $_{\mathrm{G}}$ and tenascin-R, which stains the perinodal astrocytes (ffrench-Constant et al., 1986). As shown in Figure $1 C-F$, bands of tenascin-R immunoreactivity colocalized with node-like clusters of ankyrin $_{\mathrm{G}}$ in both $m d$ and WT rats. These results indicate that the node-like clusters in $m d$ rats have the same molecular components as do nodes in WT rats.

Node-like clusters appeared to be more numerous in ventral funiculi of $m d$ rats than in P21 WT rats. We suspected that node-like clusters were more closely spaced along individual axons in $m d$ rats, but were unable show this directly. To determine whether this might be the case, we counted number of node-like clusters in transverse sections of the cervical spinal cord from three P21 md rats and three WT littermates. The sections were double-labeled with a pan- $\mathrm{Na}^{+}$channel mouse monoclonal antibody and a rabbit antiserum against $\mathrm{Na}_{\mathrm{v}} 1.6$ (see below). All of the node-like clusters stained with the pan- $\mathrm{Na}^{+}$channel in 130 $\mu \mathrm{m}^{2}$ square of the ventromedial funiculus from digital images were counted. There were $345( \pm 70)$ node-like clusters in $m d$ rats, versus $207( \pm 9.2)$ in their P21 WT littermates; these results supported the idea that there were more nodes in the ventral funiculus, but did not reach statistical significance $(p=0.08$; Student's one-tailed $t$ test).

\section{$\mathrm{Na}_{v} 1.6$ is the predominant voltage-gated $\mathrm{Na}^{+}$channel in $\boldsymbol{m d}$ spinal cord}

To determine which type 1 voltage-gated $\mathrm{Na}^{+}$channels were present in CNS nodes, we used rabbit antisera that specifically recognize $\mathrm{Na}_{\mathrm{v}} 1.2, \mathrm{Na}_{\mathrm{v}} 1.6$, and $\mathrm{Na}_{\mathrm{v}} 1.8$, all of which are expressed in the CNS (Goldin, 1999). We first compared the staining with these isoform-specific antisera to that of a pan- $\mathrm{Na}^{+}$channel mouse monoclonal antibody in transverse sections of P21 WT rats. The anti- $\mathrm{Na}_{\mathrm{v}} 1.6$ antiserum stained most of the nodes in the dorsal, lateral, and ventral funiculi and within the gray matter itself (Fig. 2E), as well as most initial segments, including those of motoneurons (data not shown). The $\mathrm{Na}_{\mathrm{v}} 1.8$ antiserum (Fig. $2 F$ ) stained nodes of some small axons in all funiculi, most abundantly in the dorsal funiculus, as well as the somatic membrane of most neurons throughout the gray matter, and an occasional initial segment. The $\mathrm{Na}_{\mathrm{v}} 1.2$ antiserum (Fig. 2D) stained the nodes of a few small myelinated fibers in all funiculi, a few initial segments in the intermediate and dorsal gray matter, and the unmyelinated axons of the corticospinal tract. The nodes labeled with the $\mathrm{Na}_{\mathrm{v}} 1.2, \mathrm{Na}_{\mathrm{v}} 1.6$, or $\mathrm{Na}_{\mathrm{v}} 1.8$ antisera, as well as the unmyelinated axons of the corticospinal tract, were also labeled with the pan$\mathrm{Na}^{+}$channel mouse monoclonal antibody (data not shown; Arroyo et al., 2001).

The above results indicate that $\mathrm{Na}_{\mathrm{v}} 1.6$ is the predominant voltage-gated $\mathrm{Na}^{+}$channel at nodes and initial segments in the spinal cord (Caldwell et al., 2000), with a minority of nodes expressing $\mathrm{Na}_{\mathrm{v}} 1.8$ followed by $\mathrm{Na}_{\mathrm{v}} 1.2$. To determine whether the axonal expression of these voltage-gated $\mathrm{Na}^{+}$channels was affected by severe dysmyelination, we double-labeled sections of P21 md spinal cords with the $\mathrm{Na}_{\mathrm{v}} 1.2, \mathrm{Na}_{\mathrm{v}} 1.6$, and $\mathrm{Na}_{\mathrm{v}} 1.8$ antisera and the pan- $\mathrm{Na}^{+}$channel monoclonal antibody. Compared with WT P21 rats, there was no apparent alteration in the spatial distribution of $\mathrm{Na}_{\mathrm{v}} 1.2, \mathrm{Na}_{\mathrm{v}} 1.6$, or $\mathrm{Na}_{\mathrm{v}} 1.8$ or pan- $\mathrm{Na}^{+}$channel staining (Fig. $2 A-C$ ): most node-like clusters and initial segments were $\mathrm{Na}_{\mathrm{v}}$ 1.6-positive; most neuronal cell membranes were $\mathrm{Na}_{\mathrm{v}}$ 1.8-positive; the corticospinal tract (CST) was $\mathrm{Na}_{\mathrm{v}} 1.2$-positive; there were node-like clusters of $\mathrm{Na}_{\mathrm{v}} 1.2, \mathrm{Na}_{\mathrm{v}} 1.6$, and $\mathrm{Na}_{\mathrm{v}} 1.8$ in the same places as in WT P21 rats. The number of $\mathrm{Na}_{\mathrm{v}} 1.6$ positive node-like clusters, however, appeared to be increased in $m d$ spinal cords, in keeping with our results of following staining with the pan- $\mathrm{Na}^{+}$channel monoclonal antibody (see above). To determine whether the proportion of $\mathrm{Na}_{\mathrm{v}}$ 1.6-positive node-like clusters was affected, we analyzed the same $130 \mu \mathrm{m}^{2}$ square of the ventromedial funiculus used to determine the number of nodelike clusters (see above). Although the number of node-like clusters tended to be higher in $m d$ spinal cords (see above), the proportion $\mathrm{Na}_{\mathrm{v}}$ 1.6-positive clusters was the same (77\%) as in $\mathrm{P} 21$ 

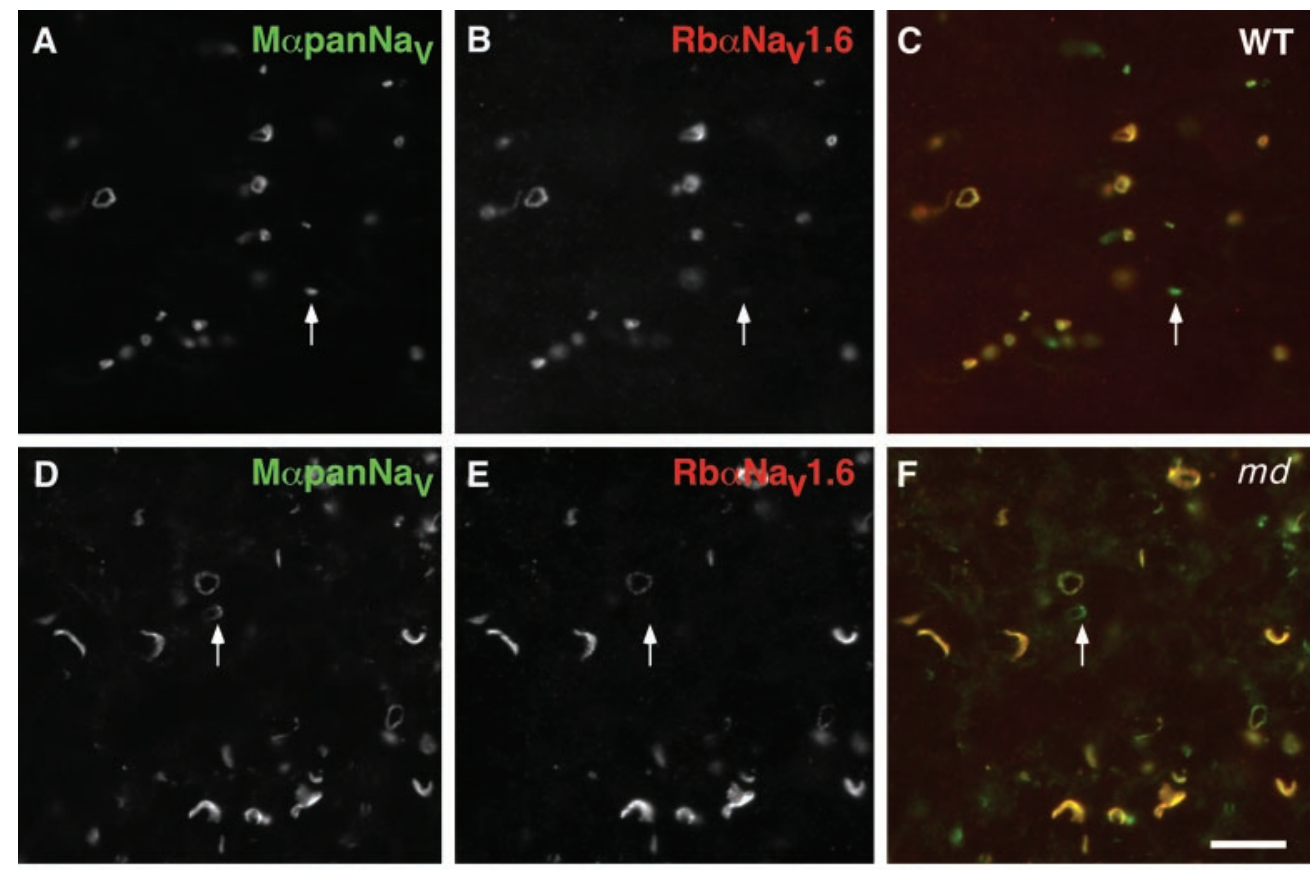

Figure 3. $\mathrm{Na}_{\mathrm{v}} 1.6$ is the predominant voltage-gated $\mathrm{Na}^{+}$channel in P21 md and WT spinal cords; Shaker-type $\mathrm{K}^{+}$ channels are not separated from $\mathrm{Na}^{+}$ channels in $m d$ spinal cord. $A-F$ are taken from transverse sections of the ventral funiculus from an $m d$ rat $(A-C)$ and its WT littermate $(D-F)$, doublelabeled with a pan- $\mathrm{Na}^{+}$channel monoclonal antibody $(A, D$; fluorescein) and a rabbit antiserum against $\mathrm{Na}_{\mathrm{v}} 1.6(B, E$; rhodamine); $C$ and $F$ show the merged images. Note the crescent-shaped nodelike clusters in $m d$ spinal cords, and that some node-like clusters are $\mathrm{Na}_{\mathrm{v}} 1.6$-negative (arrows). $G$ and $H$ are taken from a longitudinal section of an $m d(G)$ or a WT $(H)$ spinal cord, double labeled with a rabbit antiserum against Kv1.2 (TRITC) and a pan-Na ${ }^{+}$channel monoclonal antibody (FITC). In the $m d$ spinal cord, Kv1.2 abuts or even overlaps (arrows) with node-like clusters of $\mathrm{Na}^{+}$channels, whereas the unstained paranodal region separates the two types of channels in WT spinal cords. Scale bars, $10 \mu \mathrm{m}$.
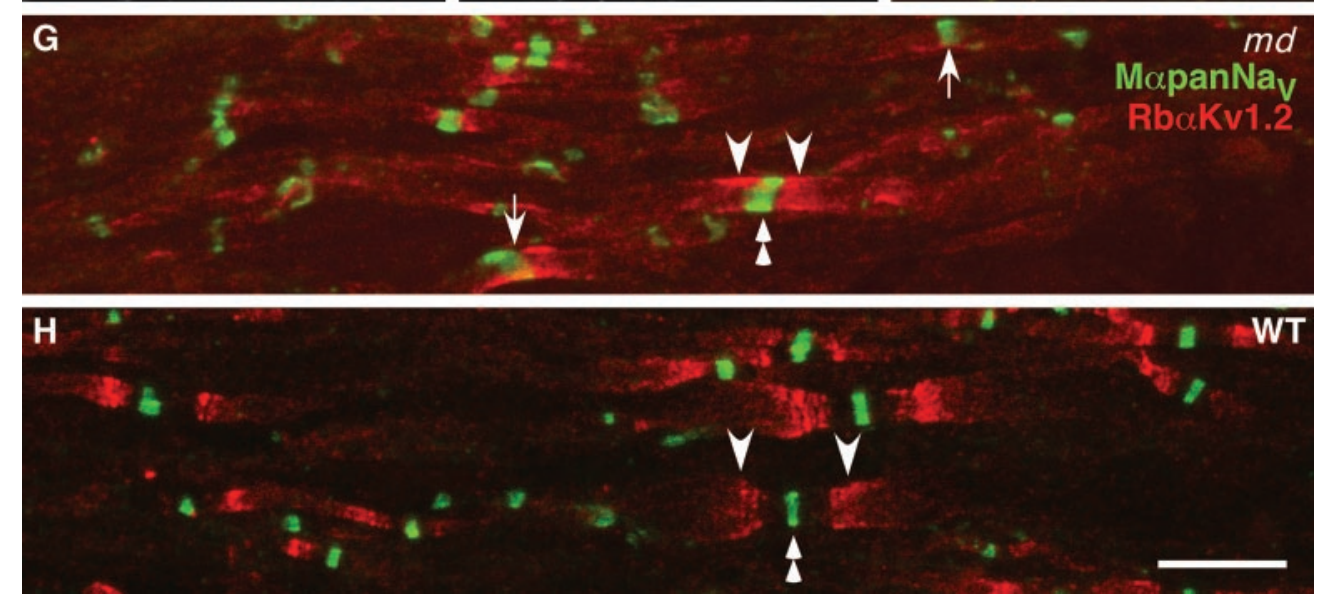

WT spinal cords ( $p=1$; ANOVA). Examples of double-labeled nodes are shown in Figure $3 A-F$.

To support these findings, we performed "blocking" experiments with the peptides that were used to generate the $\mathrm{Na}_{\mathrm{v}} 1.2$, $\mathrm{Na}_{\mathrm{v}} 1.6$, and $\mathrm{Na}_{\mathrm{v}} 1.8$ antisera and immunoblot analysis. Preincubation of these antisera with their cognate peptides greatly attenuated all aspects the staining described above (data not shown). Finally, $\mathrm{Na}_{\mathrm{v}} 1.7$ and $\mathrm{Na}_{\mathrm{v}} 1.9$ antisera did not label nodes in the CNS in either WT or $m d$ spinal cords, although there was $\mathrm{Na}_{\mathrm{v}} 1.9$ staining of what appeared to be unmyelinated afferents in the dorsal horn (data not shown; Fjell et al., 2000). Immunoblot analysis for $\mathrm{Na}_{\mathrm{v}} 1.2, \mathrm{Na}_{\mathrm{v}} 1.6$, and $\mathrm{Na}_{\mathrm{v}} 1.8$ revealed comparable levels of these voltage-gated $\mathrm{Na}^{+}$channels in $m d$ and WT spinal cords (Fig. 4).

\section{Juxtaparanodal and internodal specializations in mo rats}

In normal myelinated fibers, $\mathrm{Kv} 1.1, \mathrm{Kv} 1.2, \mathrm{Kv} \beta 2$, and $\mathrm{Caspr} 2$ are found at highest levels in juxtaparanodes and at lower levels in the internodes and paranodes, but they are not found at nodes (Arroyo and Scherer, 2000; Peles and Salzer, 2000; Rasband and Shrager, 2000). To investigate the localization of these proteins in md spinal cords, we stained longitudinal sections with mouse monoclonal antibodies and rabbit antisera against Kv1.1 and Kv1.2 (Table 1). In contrast to WT P21 spinal cords (Fig. 3H), Kv1.1 and Kv1.2 were more diffusely localized in $m d$ rats (Fig. $3 G)$. Furthermore, Kv1.1 and Kv1.2 staining frequently abutted or even overlapped that of voltage-gated $\mathrm{Na}^{+}$channels; this was never seen in WT spinal cords. Double-labeling for Kv1.1 and Kv1.2 demonstrated that these two channels were co-localized even in their abnormal distributions in $m d$ rats, as they are in WT rats and mice (data not shown). We could not perform comparable analyses for $\mathrm{Kv} \beta 2$ and Caspr2, because these antibodies stained too weakly in the fixed material (data not shown).

\section{Contactin, Caspr, and NF155 are not localized to paranodes in $\boldsymbol{m d}$ rats}

The lack of separation between Kv1.1 and Kv1.2 $\mathrm{K}^{+}$channels and voltage-gated $\mathrm{Na}^{+}$channels in $m d$ rats led us to examine the expression of the paranodal proteins, contactin, Caspr, and NF155. In sections of P21 WT spinal cord, these proteins were colocalized to paranodes with multiple antibodies (Table 1). In $m d$ spinal cords, however, none of these proteins were localized to the paranodal region. Rather, there were diff use staining in the white matter for contactin, Caspr, and NF155, and staining of oligodendrocyte cell bodies for NF155 (Tait et al., 2000). In the 


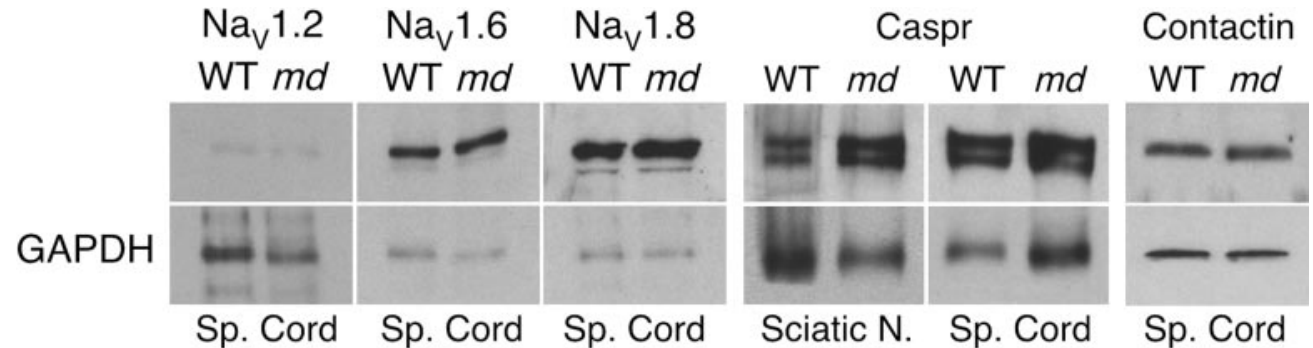

Figure 4. Immunoblot analysis of voltage-gated $\mathrm{Na}^{+}$channels, contactin, and Caspr. Homogenates of spinal cords and sciatic nerves were prepared from P21 $m d$ and their WT littermates, and $100 \mu \mathrm{g}$ of protein was analyzed for $\mathrm{Na}_{\mathrm{v}} 1.2, \mathrm{Na}_{\mathrm{v}} 1.6, \mathrm{Na}_{\mathrm{v}} 1.8$, Caspr, and contactin. For $\mathrm{Na}_{\mathrm{v}} 1.2, \mathrm{Na}_{\mathrm{v}} 1.6, \mathrm{Na}_{\mathrm{v}} 1.8$, the films were exposed for $20 \mathrm{~min}$, then rehybridized with a mouse monoclonal antibody to GAPDH, and exposed to film for $5 \mathrm{~min}$. For Caspr, the film was exposed for $30 \mathrm{sec}$, then rehybridized with a mouse monoclonal antibody to GAPDH, and exposed to film for 30 sec. For contactin, the film was exposed for $5 \mathrm{sec}$, then rehybridized with a mouse monoclonal antibody to GAPDH, and exposed to film for 2 min. The $\mathrm{Na}_{\mathrm{v}} 1.2, \mathrm{Na}_{\mathrm{v}} 1.6$, and $\mathrm{Na}_{\mathrm{v}} 1.8$, bands were all $\sim 250 \mathrm{kDa}$; the Caspr doublet band $\sim 190 \mathrm{kDa}$; the contactin band $\sim 135 \mathrm{kDa}$. Note the similar amounts of $\mathrm{Na}_{\mathrm{v}} 1.2, \mathrm{Na}_{\mathrm{v}} 1.6, \mathrm{Na}_{\mathrm{v}} 1.8, \mathrm{Caspr}$, and contactin in $m d$ and WT samples.
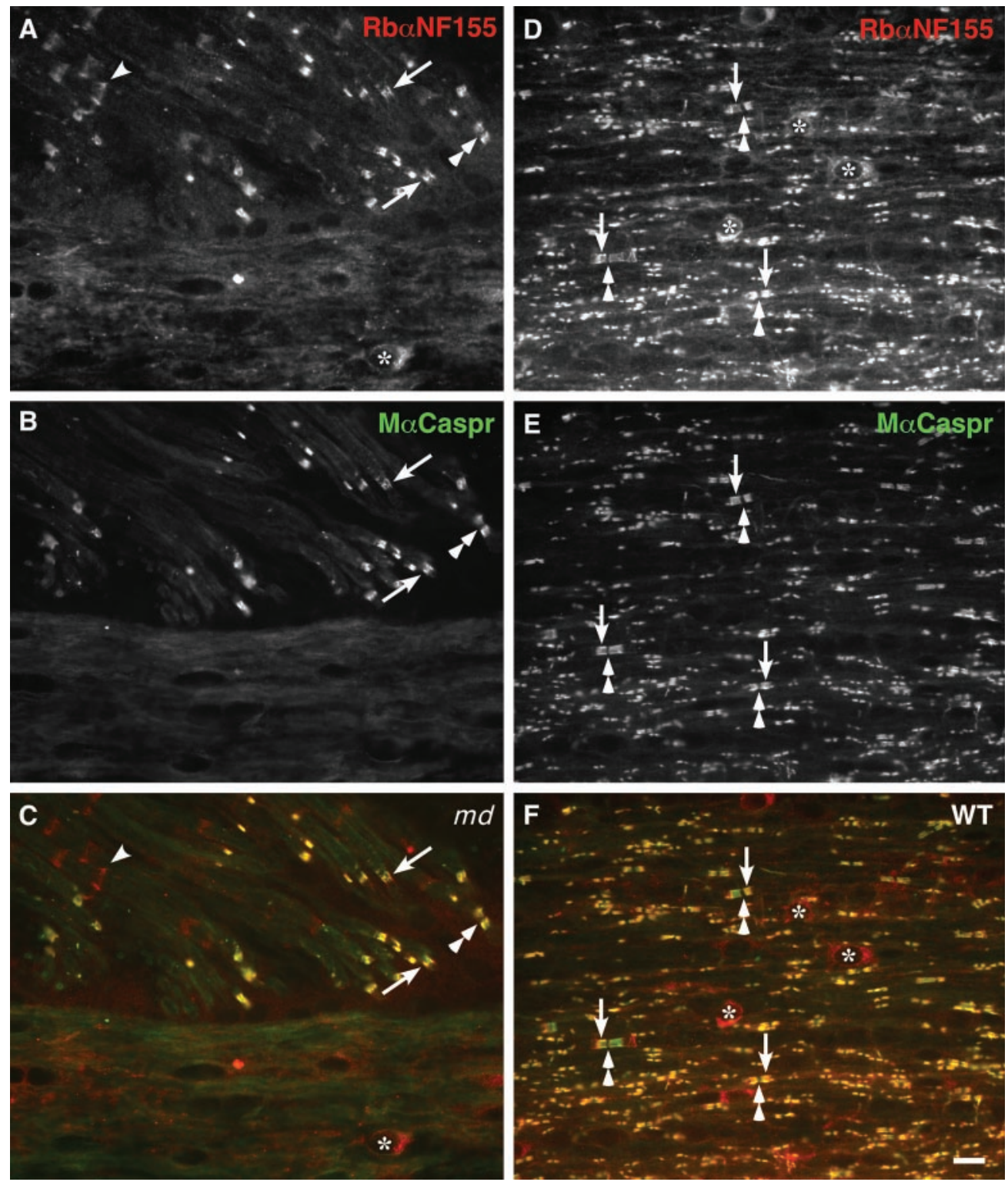

Figure 5. Caspr and neurofascin are not localized to CNS paranodes in $m d$ rats. These images were made from longitudinal sections of $\mathrm{P} 21 m d(A-C)$ or WT $(D-F)$ spinal cord, after doublelabeling with a rabbit antiserum against NF155 ( $A, D$; TRITC) and a mouse monoclonal antibody against $C$ aspr $(B$, $E$; FITC); $C$ and $F$ show the merged images. In $m d$ rats, Caspr and neurofascin are colocalized in the paranodes in the ventral roots (arrows) but not in the spinal cord. The arrowhead marks an incisure, which is stained for NF155 but not for Caspr (Tait et al., 2000). In WT rats, Caspr and NF155 are colocalized at all CNS paranodes. Asterisks mark oligodendrocyte cell bodies, which are stained for NF155 but not Caspr (Tait et al., 2000); double arrowheads mark nodes. Scale bar, $10 \mu \mathrm{m}$. ventral and dorsal rootlets, however, in which the axons are myelinated by Schwann cells, Caspr, contactin, and NF155 completely overlap at paranodes (Fig. 5), presumably because PNS myelination is normal in $m d$ rats (Dentinger et al., 1982).

To determine whether the altered distribution of contactin, Caspr, Kv1.1, and Kv1.2 was associated with altered amounts of these proteins, we performed immunoblot analysis. As shown in Figure 4, the amount of contactin and Caspr were similar in P21 $m d$ rat spinal cords and in their WT littermates. Immunoblotting for Kv1.1 and Kv1.2 was unsuccessful. These results indicate that the aberrant myelination in $m d$ rats causes the redistribution of contactin and Caspr without altering their overall levels. 
Figure 6. Electron microscopy of P21 $m d$ spinal cord. These are electron micrographs of transverse $(A, B)$ and longitudinal $(C-E)$ sections of the ventromedial funiculus. In $A$ and $C$, note several large axons $(a x)$ that are not myelinated. $A$ shows a portion of an oligodendrocyte $(o l)$ with dilated cisternae; these are common in $m d$ rats. $B$ shows one axon in higher magnification; note the multiple processes (asterisks) surrounding the axon. $D$ and $E$ show the rectangular regions; note the astrocytic processes (as) in $D$ and the stack of five oligodendrocyte processes in $E$.
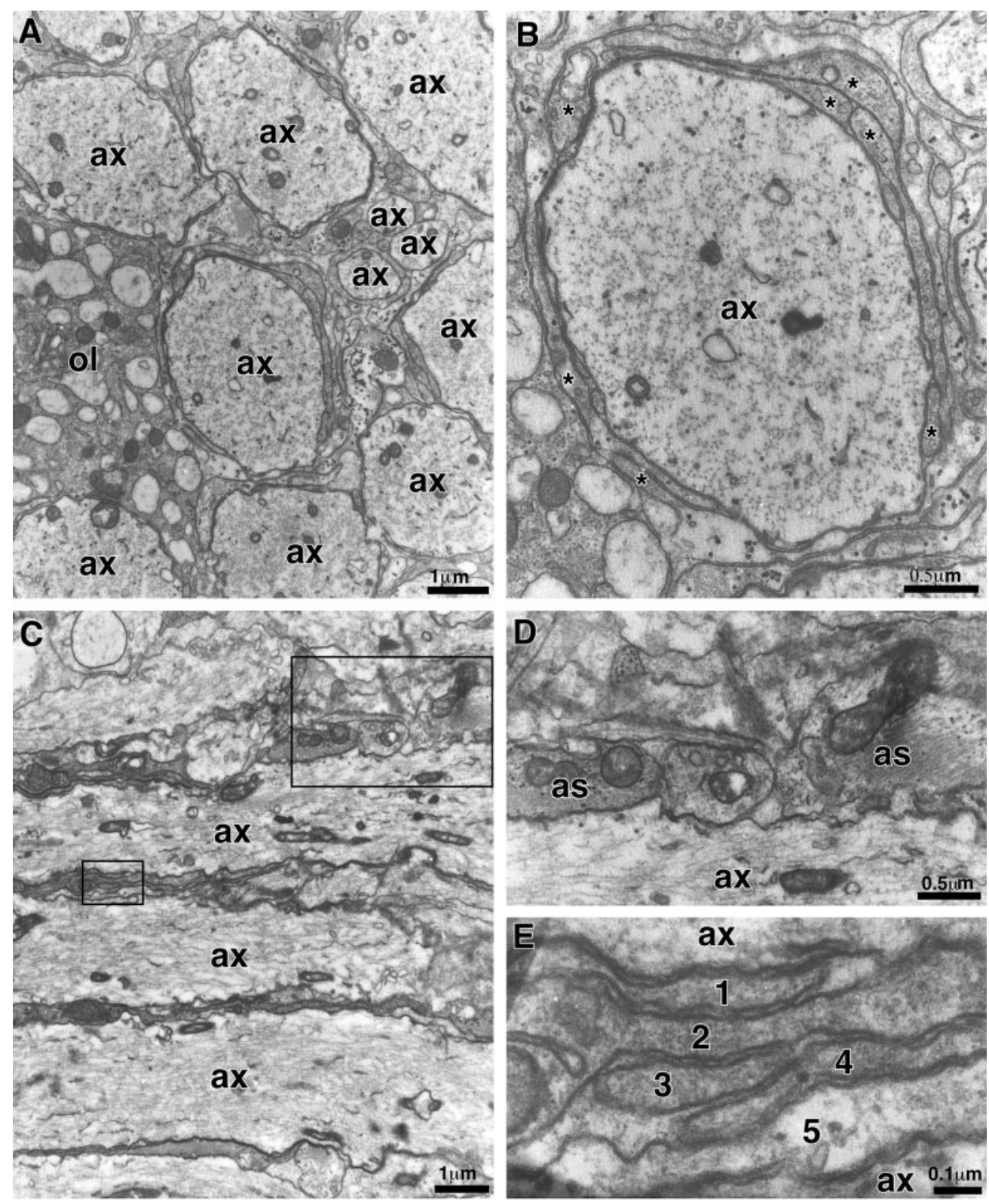

\section{Paranodal specializations in the absence of myelination?}

The above data, taken together, indicate that the lack of paranodal specializations in $m d$ spinal cords results in the lack of separation between $\mathrm{Kv} 1.1$ and $\mathrm{Kv} 1.2 \mathrm{~K}^{+}$channels and voltagegated $\mathrm{Na}^{+}$channels. To investigate axon-oligodendrocyte interactions further, we examined P21 md spinal cords by electron microscopy, focusing on the ensheathment of the largest axons in the ventral funiculus, as these would normally be well myelinated. In transverse sections, the ventral funiculi had few myelinated fibers $(<1 \%$ of axons larger than $2 \mu \mathrm{m}$ in diameter); these had thin myelin sheaths whose characteristics have been previously described (Dentinger et al., 1982; Barron et al., 1987; Duncan et al., 1987; Rosenbluth, 1987). The few myelinated fibers that we found in longitudinal sections had disorganized paranodes; the glial endfeet were chaotically arranged, and even those apposed to the axolemma often did not terminate on it owing to the intrusion of astrocytic processes (Rosenbluth, 1987). Septate-like junctions-transverse bands were not seen even when the terminal loops directly apposed the axolemma (Rosenbluth, 1987).

We were particularly interested in one aspect that has not been previously emphasized; most large myelinated axons were individually ensheathed by glial processes (Fig. $6 A, B$ ). Many of these processes appeared to belong to oligodendrocytes because they contained relatively electron-dense cytoplasm and lacked intermediate filaments; some processes were focally devoid of cytoplasm, and thus appeared like a single wrap of compact myelin. In transverse sections, most large axons were at least partly surrounded by oligodendrocyte processes, often by more than one process, but some large axons also apposed astrocytes as well as other axons. In longitudinal sections (Fig. 6C-E), it was apparent that oligodendrocytic processes typically ensheathed large axons for short distances $(<10 \mu \mathrm{m})$ and abutted other oligodendrocyte processes or even astrocytic processes. No paranodal specializations such as septate-like junctions were seen between oligodendrocyte processes and ensheathed axons. 

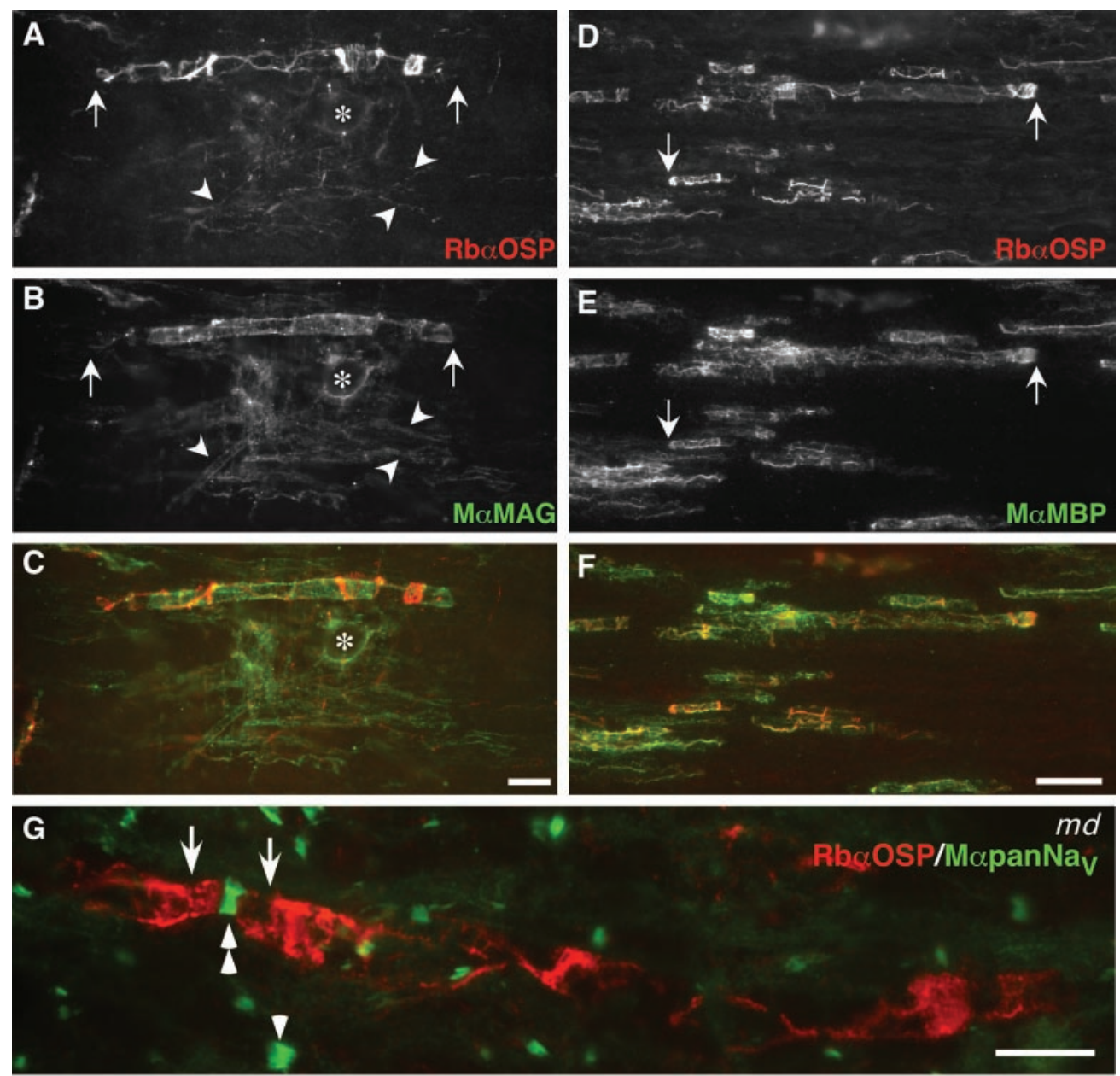

md

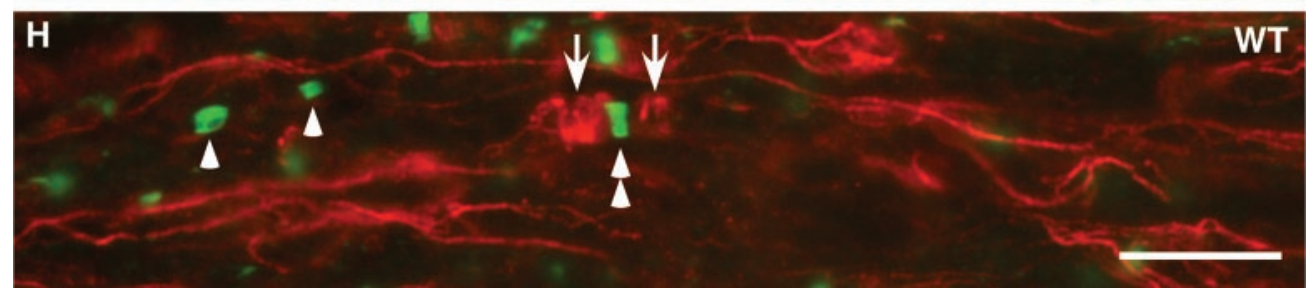

Figure 7. MAG-, MBP-, and OSPpositive oligodendrocytes ensheathe axons in $m d$ spinal cord. These images are taken from longitudinal sections of a $\mathrm{P} 21 m d(A-G)$ or a WT $(H)$ spinal cord, double labeled with a rabbit antiserum against OSP (TRITC) and a monoclonal antibodies (FITC) against MAG $(A-C)$, MBP $(C-F)$, or pan-Na ${ }^{+}$ channels $(G, H)$. As in WT rats $(G)$, the paranodes in $m d$ rats contain a spiral of OSP staining (arrows), and (MBPand MAG-positive) internodes-oligodendrocyte processes often contain OSP-positive strands. An asterisk marks an oligodendrocyte nucleus in $A-C$. In $G$ and $H$, paranodal OSP staining (arrows) flanks most node-like clusters of $\mathrm{Na}^{+}$channels (double arrowheads) in WT rats, but many node-like clusters are not associated with paranodal OSP staining in $m d$ rats. Scale bars: $A-C, G$, $H, 10 \mu \mathrm{m} ; D-F, 20 \mu \mathrm{m}$.

\section{Oligodendrocytes ensheathe axons in $m d$ rats}

The ultrastructure of $m d$ spinal cords indicated that many large axons are ensheathed by oligodendrocytes, yet are not myelinated. To visualize how oligodendrocytes ensheathe axons, we labeled longitudinal sections. We used antibodies that stained oligodendrocytes based on our previous study of $m d$ rats [Rip, MAG, myelin-oligodendrocyte glycoprotein (MOG), and MBP] (Grinspan et al., 1996), as well antisera against claudin-11 [also known as oligodendrocyte-specific protein (OSP)] (Table 1). Rip, MAG, MBP, MOG, and claudin-11/OSP antibodies labeled particularly well several myelin sheaths in most high-power fields. As shown in Figure 7, these well stained sheaths typically had one or more strands of claudin-11/OSP staining that extended from end to end, and bands of staining at the two ends, likely corresponding to paranodes (Gow et al., 1999; Morita et al., 1999). Although some of these highly stained sheaths probably correspond to the myelin sheaths seen by electron microscopy, they were much more numerous, demonstrating that many axons are ensheathed by oligodendrocyte processes but not myelinated. These studies also demonstrated that the Rip and MAG antibodies stain oligoden- drocytes and their processes more completely than the other antibodies we examined (Fig. 6A-F).

\section{The development of node-like clusters in $\mathbf{m d}$ rat spinal cords}

We wished to determine the relationship between node-like clusters and oligodendrocyte ensheathment. We selected antibodies that reliably stain oligodendrocytes (against MAG, Rip, MOG, MBP), and antibodies that labeled paranodes (against claudin11/OSP, but not against contactin, Caspr, and NF155) combined with antibodies that label node-like clusters (either the pan- $\mathrm{Na}^{+}$ channel monoclonal antibody or the rabbit antisera against $\mathrm{Na}_{\mathrm{v}} 1.6$ or ankryin ${ }_{\mathrm{G}}$ ). Double-labeled longitudinal sections of P21 $m d$ rat ventral funiculi revealed that node-like clusters of $\mathrm{Na}^{+}$channelsankryin $_{\mathrm{G}}$ were often adjacent to ensheathed axonal segments, regardless of whether the oligodendrocytes were labeled for claudin-11/OSP (Fig. 7G), MAG (Fig. 8A), MBP (Fig. 8B), Rip (data not shown), or MOG (data not shown). By comparison, claudin11/OSP was by far the most useful of these antibodies in labeling paranodes in P21 WT spinal cord (Fig. $6 H$ ), because the amount 

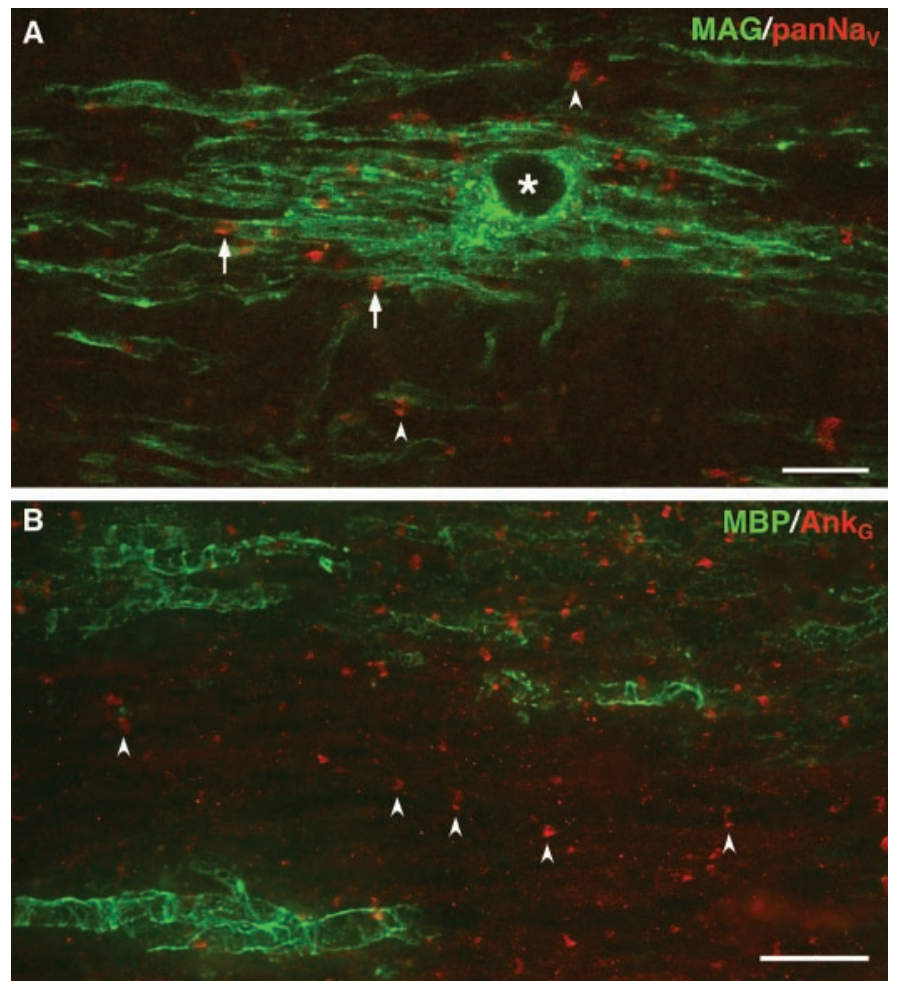

Figure 8. Clusters of $\mathrm{Na}^{+}$channels and ankryin ${ }_{\mathrm{G}}$ in regions devoid of oligodendrocytes. These images were taken from longitudinal sections of P21 $m d$ spinal cord, stained with a rabbit antiserum against MAG and a pan- $\mathrm{Na}^{+}$channel monoclonal antibody ( $A$; merged confocal images), or a rabbit antiserum against ankyrin $_{\mathrm{G}}$ and a mouse monoclonal antibody against MBP ( $B$; merged epifluorescence images). Note the clusters of $\mathrm{Na}^{+}$channels and ankyrin $_{\mathrm{G}}$ staining in regions that are devoid of MAGMBP staining (arrowheads), as well as adjacent to MAG-MBP-positive processes (arrows). An asterisk marks an oligodendrocyte nucleus. Scale bars: $A, 10 \mu \mathrm{m} ; B, 20 \mu \mathrm{m}$.

of staining with these other antibodies made it difficult to find the paranodes (data not shown).

Most node-like clusters, however, were not adjacent to ensheathed axonal segments; many were in areas that lacked oligodendrocytes altogether (Figs. $7 G, 8 A, B$ ). These results indicate that oligodendrocyte ensheathment may not be necessary for the formation node-like clusters, or that node-like clusters form adjacent to ensheathed axonal segments but persist after becoming isolated following oligodendrocyte cell death (Gow et al., 1998; Grinspan et al., 1998; Lipsitz et al., 1998). To evaluate the latter possibility, we labeled longitudinal sections of the ventral funiculus from the cervical cord from P7 (four $m d$ rats and four WT), $\mathrm{P} 14$ (two $m d$ and two WT), and P21 rats (two $m d$ and two WT) with the pan $\mathrm{Na}^{+}$channel monoclonal antibody (to label nodes) and a rabbit antiserum against MAG (to label ensheathed axonal segments). We counted and classified the node-like clusters in relation to the MAG staining, as either clusters (not associated with MAG staining), heminodes (MAG staining present on one side of the cluster), or nodes (MAG staining present on both sides of the cluster); these data are summarized in Figure 9 and Table 2. Note that the percentage of nodes increases in WT rats from P7 to $\mathrm{P} 21$, whereas in $m d$ rats, the proportion declines; at $\mathrm{P} 7$, the percentage of nodes is similar between $m d$ and WT rats, but it is significantly different at P14 and P21. Thus, these data indicate that isolated node-like clusters in P21 $m d$ rats result from oligodendrocyte cell death during development.

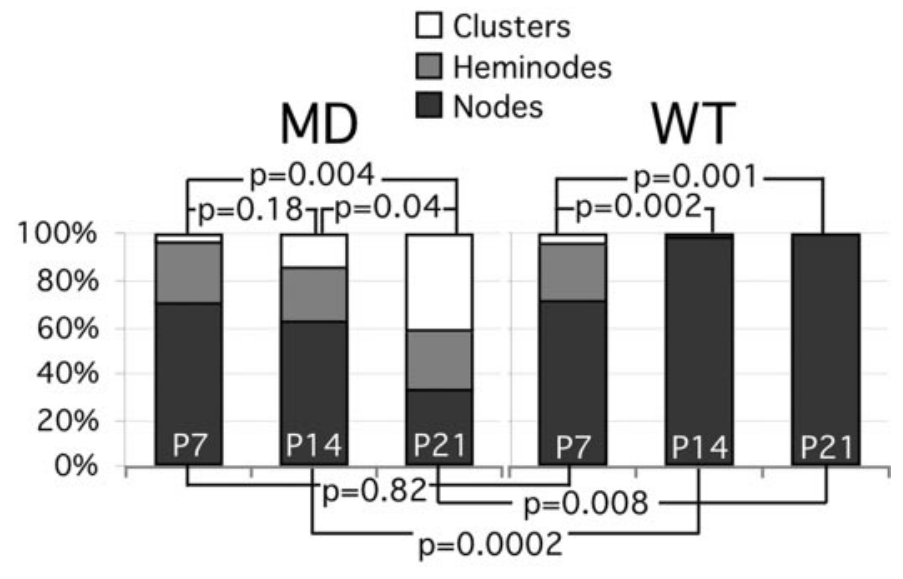

Figure 9. Quantitative analysis of node-like clusters in the ventral funiculus. Longitudinal sections through the ventral funiculus of P7 (4 md and 4 WT), P14 ( $2 m d$ and 2 WT), and P21 ( $2 m d$ and 2 WT) were double-labeled with the pan $\mathrm{Na}^{+}$channel monoclonal antibody (to label nodes) and the rabbit antiserum against MAG (to label ensheathed axonal segments). All node-like clusters of $\mathrm{Na}^{+}$channels were classified as either naked clusters (not flanked by MAG-positive ensheathed axonal segments), heminodes (flanked on only side one by MAG-positive axonal segments), or nodes (flanked on both sides by MAG-positive axonal segments). The percentage of nodes was calculated at each age; ANOVA statistical analyses were used to compare the samples; the $p$ values are shown for each comparison.

In the developing optic nerve, node-like clusters of voltagegated $\mathrm{Na}^{+}$channels form adjacent to paranodes, as marked by Caspr staining (Rasband and Trimmer, 2001a). Our results also demonstrate that node-like clusters of voltage-gated $\mathrm{Na}^{+}$channels develop adjacent to ensheathed axons, as marked by MAGstaining. However, because contactin, Caspr, and NF155 are not localized to paranodes in $\mathrm{P} 21 \mathrm{md}$ rats, septate-like junctions do not appear to be necessary for the clustering of voltage-gated $\mathrm{Na}^{+}$channels. To exclude the possibility that these components of septate-like junctions might be initially present, but lost by P21, we examined longitudinal sections of P7 and P14 rat spinal cord that were double-labeled with antisera against contactin, Caspr, or NF155 and the pan-Na ${ }^{+}$channels monoclonal antibody. In contrast to WT rats, we did not find any evidence for paranodal clustering of contactin, Caspr, or NF155 in $m d$ rats (data not shown). Thus, although voltage-gated $\mathrm{Na}^{+}$channels form adjacent to paranodes in $\mathrm{WT}$ and $m d$ rats, septate-like junctions do not appear to be necessary for this to occur.

\section{DISCUSSION}

The molecular organization of axons in $m d$ rats is severely altered, as summarized in Figure 10. Oligodendrocytes ensheathe short segments of many large axons, but form few myelin sheaths. The axoglial junctions of these ensheathed axons, and even of the myelinated axons, lack septate-like junctions, and contactin, Caspr, and NF155 do not accumulate at paranodes. Nevertheless, node-like clusters form adjacent to ensheathed axonal segments and persist after oligodendrocyte cell death. The distribution of $\mathrm{Na}_{\mathrm{v}} 1.2, \mathrm{Na}_{\mathrm{v}} 1.6$, and $\mathrm{Na}_{\mathrm{v}} 1.8$ clusters, and the number $\mathrm{Na}_{\mathrm{v}} 1.6$ clusters in $m d$ rats are comparable to those in age-matched WT spinal cords. Kv1.1 and Kv1.2 abut and even overlap node-like clusters of voltage-gated $\mathrm{Na}^{+}$channels and ankryin $\mathrm{G}$. 


\begin{tabular}{|c|c|c|c|c|c|c|c|c|c|}
\hline & \multicolumn{4}{|c|}{ Myelin-deficient } & \multicolumn{4}{|c|}{ Wild-type } & \multirow{2}{*}{$\begin{array}{l}\text { MD vs WT } \\
\% \text { Nodes } \\
p \text { values }\end{array}$} \\
\hline & Nodes & Heminodes & Clusters & $\%$ Nodes & Nodes & Heminodes & Clusters & $\%$ Nodes & \\
\hline \multirow[t]{4}{*}{ P7 } & 79 & 21 & 5 & 75 & 42 & 18 & 4 & 65 & \multirow[t]{4}{*}{0.82} \\
\hline & 43 & 22 & 7 & 60 & 56 & 23 & 1 & 70 & \\
\hline & 57 & 23 & 1 & 70 & 78 & 28 & 4 & 71 & \\
\hline & 44 & 14 & 1 & 75 & 55 & 14 & 2 & 77 & \\
\hline \multirow[t]{2}{*}{ P14 } & 166 & 62 & 39 & 62 & 146 & 5 & 0 & 97 & \multirow[t]{2}{*}{0.0002} \\
\hline & 126 & 47 & 31 & 62 & 170 & 4 & 0 & 98 & \\
\hline \multirow[t]{2}{*}{ P21 } & 99 & 118 & 164 & 26 & 113 & 1 & 0 & 99 & \multirow[t]{2}{*}{0.008} \\
\hline & 95 & 54 & 101 & 38 & 121 & 2 & 0 & 98 & \\
\hline
\end{tabular}

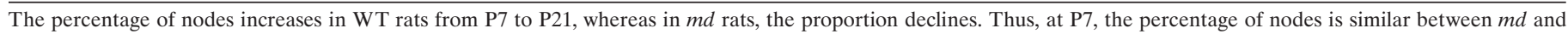
WT, but it is significantly different at P14 and P21.

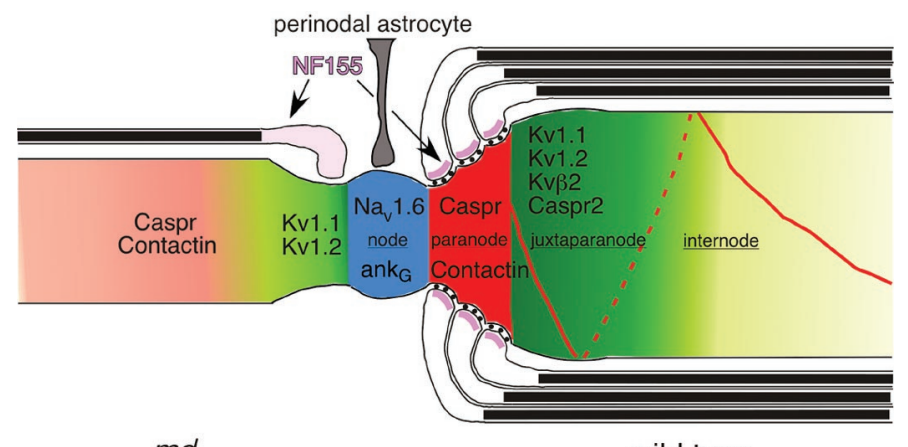

md

Figure 10. The organization of the axonal membrane in $m d$ rats. In this schematic image, the axon is depicted as intact, whereas the glial cells are depicted as being hemisected, to reveal the axoglial junctions. The localization of nodal (blue; voltage-gated $\mathrm{Na}^{+}$channels and ankyrin ${ }_{\mathrm{G}}$ ), paranodal (red for contactin and Caspr; purple for NF155), and juxtaparanodal proteins ( green; Kv1.1, Kv1.2, Kv $\beta 2$, Caspr2) in WT rats are shown on the right. The left side of the figure depicts that in $\mathrm{P} 21 \mathrm{md}$ rats, nodal proteins can be localized with or without oligodendrocyte ensheathment, whereas contactin and Caspr are diffusely localized, and Kv1.1 and Kv1.2 abut the nodal membrane.

\section{The localization of $\mathrm{Na}_{v} 1.2, \mathrm{Na}_{\mathrm{v}} 1.6$, and $\mathrm{Na}_{\mathrm{v}} 1.8$ in the spinal cord of normal rats}

Our observations of WT spinal cord confirm and extend previous studies of voltage-gated $\mathrm{Na}^{+}$channels in the CNS. That the CST contains abundant $\mathrm{Na}_{\mathrm{v}} 1.2$ is consistent with previous reports that $\mathrm{Na}_{\mathrm{v}} 1.2$ is highly expressed by unmyelinated axons and in gray matter (Westenbroek et al., 1989), because the CST contains abundant unmyelinated axons (Langford and Coggeshall, 1981). Although all nodes in adult optic nerve (a CNS myelinated tract) contained $\mathrm{Na}_{\mathrm{v}} 1.6$ (Caldwell et al., 2000; Boiko et al., 2001), our data show that different neurons express at least two other voltage-gated $\mathrm{Na}^{+}$channels. Finally, to our knowledge, the somatic membrane staining of $\mathrm{Na}_{\mathrm{v}} 1.8$ have not been reported, although $\mathrm{Na}_{\mathrm{v}} 1.8$ mRNA has been detected (Schaller and Caldwell, 2000).

\section{The organization axonal proteins in dysmyelinating mutants}

There are two previous reports on the molecular organization of myelinated axons in $m d$ rats. The monoclonal antibody HNK-1 stains the optic nerve diffusely (Struckhoff et al., 1997), whereas it stains perinodal astrocytes in WT optic nerves (ffrench-
Constant and Raff, 1986). Thus, we expected to find diffuse tenascin- $\mathrm{R}$ staining, because tenascin- $\mathrm{R}$ is the only molecule localized to perinodal astrocytes that has an HNK-1 epitope (ffrench-Constant et al., 1986). Kaplan et al. (1997) examined the optic nerves of P10 and P16 WT and $m d$ rats, and found fewer node-like clusters of voltage-gated $\mathrm{Na}^{+}$channels in $m d$ rats. Our findings demonstrate that the number of node-like clusters in the ventral funiculus of $m d$ rats is not reduced at P21. Whether this discrepancy is related to the later onset of myelination in the rat optic nerve (P10) (Hildebrand and Waxman, 1984; Trimmer and Wunderlich, 1990), as compared to the ventral funiculus (P1) (Baron et al., 1993), or another difference between the neuronal populations remains to be determined.

The molecular organization of myelinated axons has been examined in other genetic models of CNS dysmyelination. In $P l p^{\text {jimpy }}$ mice, which have a similarly severe phenotype to $m d$ rats, Baba et al. (1999) described diff use staining of $\mathrm{Kv} \beta 2$ except where myelinated axons are formed, and one can presume that Kv1.1, Kv1.2, and Caspr2 would be similarly distributed. Homozygous shiverer mice have a recessive mutation that results in a complete absence of MBP, but they are much longer lived, and oligodendrocyte cell death is not a prominent feature. Like md rats, shiverer oligodendrocytes ensheathe but do not myelinate axons; unlike $m d$ rats, shiverer mice have elaborate paranode-like specializations (Rosenbluth, 1981) that likely correspond to the pattern of Caspr and NF155 staining described by Tait et al. (2000). The lack of normal paranodes in shiverer mice may explain why Kv1.1 and Kv1.2 staining in their CNS tracts (that would be myelinated in WT mice) was described as "diff use" (Wang et al., 1995). How nodal clusters of $\mathrm{Na}^{+}$channels are affected in shiverer mice is less clear. The number of $\mathrm{Na}^{+}$channels are increased in shiverer optic nerve (Noebels et al., 1991), and that there appears to be a diffuse increase in $\mathrm{Na}_{\mathrm{v}} 1.2$ channels (Westenbroek et al., 1992; Boiko et al., 2001). In contrast, using pan- $\mathrm{Na}^{+}$channel antibodies, Rasband et al. (1999) found node-like clusters of $\mathrm{Na}^{+}$ channels in shiverer optic nerve, although fewer in number than in age-matched WT mice. These clusters were typically irregular in appearance, did not colocalize with ankryin $_{\mathrm{G}}$, and about onequarter of them were not adjacent clusters of Caspr staining. Recently, Boiko et al. (2001) reported a developmental delay in the appearance of $\mathrm{Na}_{\mathrm{v}}$ 1.6-positive node-like clusters in shiverer optic nerve. At P40, only a few nodes were $\mathrm{Na}_{\mathrm{v}} 1.6$-positive in shiverer optic nerves (and these were the ones flanked by Casprpositive paranodes), whereas all nodes were $\mathrm{Na}_{\mathrm{v}} 1.6$-positive in WT optic nerves. 
In contrast to some of the above findings, in the $m d$ rat spinal cord, the number of $\mathrm{Na}^{+}$channel clusters was not decreased compared with WT male littermates, and all of these clusters

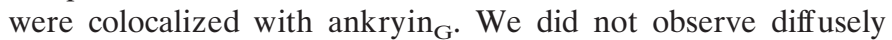
increased levels of $\mathrm{Na}^{+}$channel staining, with either the pan- $\mathrm{Na}^{+}$ channel antibodies, or the antisera specific for $\mathrm{Na}_{\mathrm{v}} 1.2, \mathrm{Na}_{\mathrm{v}} 1.6$, or $\mathrm{Na}_{\mathrm{v}} 1.8$, by immunostaining or immunoblot analysis. Moreover, the topology of $\mathrm{Na}_{\mathrm{v}} 1.2, \mathrm{Na}_{\mathrm{v}} 1.6$, or $\mathrm{Na}_{\mathrm{v}} 1.8$ staining was not altered in $m d$ spinal cord, calling into question the generality of the finding that $\mathrm{Na}_{\mathrm{v}} 1.2$ is "maintained" by the dysmyelination in shiverer optic nerve (Westenbroek et al., 1989; Caldwell et al., 2000; Boiko et al., 2001). The failure of Rasband et al. (1999) to find colocation with ankryin $_{\mathrm{G}}$ could reflect a real difference between these mutant animals, or a technical issue, as they used a different antiserum against ankryin ${ }_{\mathrm{G}}$. The most striking difference, however, is the lack of clusters of contactin, Caspr, or NF155 in $m d$ rats as apposed to shiverer mice. The lack of these clusters nicely correlates with the lack of septate-like junctionsterminal bands between oligodendrocyte processes and axons in $m d$ rats, as compared with shiverer mice, in which there are abundant, but disorganized septate-like junctions at axo-glial junctions (Rosenbluth, 1981, 1987, 1995).

\section{Septate-like junctions are not required for the formation of node-like clusters}

Our data demonstrate that node-like clusters of voltage-gated $\mathrm{Na}^{+}$channels and ankyrin ${ }_{\mathrm{G}}$ form adjacent to ensheathed axon segments and become isolated after oligodendrocyte cell death. Furthermore, these node-like clusters form in the absence of septate-like junctions or the paranodal accumulation of contactin, Caspr, or NF155. These data confirm and extend similar findings from mice that lack contactin (Boyle et al., 2001) or Caspr (Bhat et al., 2001), or in cgt-null mice, in which NF155 does not cluster at the axoglial junctions (Dupree et al., 1999; Poliak et al., 2001). In these mice, however, myelin sheaths are well formed, whereas in $m d$ rats, axons are ensheathed by oligodendrocytes but seldom myelinated. Thus, there appears to be a mechanism that causes nodes to form adjacent to ensheathed axons independent of septate-like junctions; whether this is related to the oligodendrocyte-derived clustering factor (Kaplan et al., 1997, 2001) remains to be determined.

\section{Paranodal specializations exclude Kv1.1 and Kv1.2 channels}

Our finding that Kv1.1 and Kv1.2 abut nodes has also been reported in contactin-, Caspr-, and cgt-null mice (Dupree et al., 1999; Bhat et al., 2001; Boyle et al., 2001; Poliak et al., 2001). The common denominator in all these mutant mice is that contactin, Caspr, and NF155 are mislocalized, and that septate-like junctions do not form. The absence of a stable complex of contactin, Caspr, and NF155 may allow the complex of Caspr2 (and its associated molecules, Kv1.1, and Kv1.2) to be maintained in the paranodal region by its interactions with band 4.1B (Poliak et al., 2001). These juxtaposed Kv1.1 and Kv1.2 channels likely interfere with the propagation of action potentials (Popko, 2000; Boyle et al., 2001) and may play the key role in the pathogenesis of demyelinating diseases.

\section{REFERENCES}

Arroyo EJ, Scherer SS (2000) On the molecular architecture of myelinated fibers. Histochem Cell Biol 113:1-18.

Arroyo EJ, Xu T, Poliak S, Watson M, Peles E, Scherer SS (2001) Internodal specializations of myelinated axons in the CNS. Cell Tissue Res 305:53-66.
Baba H, Akita H, Ishibashi T, Inoue Y, Nakahira K, Ikenaka K (1999) Completion of myelin compaction, but not the attachment of oligodendroglial processes triggers $\mathrm{K}+$ channel clustering. J Neurosci Res 58:752-764.

Baron P, Kamholz J, Scherer SS, Honda Scherer, Shy M, Scarpini E, Scarlato G, Pleasure D (1993) Appearance of PLP mRNA in specific regions of the developing rat lumbosacral spinal cord as revealed by in situ hybridization. Exp Neurol 121:139-147.

Barron KD, Dentinger MP, Csiza CK, Keegan SM, Mankes R (1987) Abnormalities of central axons in a dysmyelinative rat mutant. Exp Mol Pathol 47:125-142.

Bhat MA, Rios JC, Lu Y, Garcia-Fresco GP, Ching W, St Martin M, Li JJ, Einheber S, Chesler M, Rosenbluth J, Salzer JL, Bellen HJ (2001) Axon-glia interactions, the domain organization of myelinated axons requires Neurexin IV/Caspr/Paranodin. Neuron 30:369-383.

Boiko T, Rasb MN, Levinson SR, Coldwell JH, Mandel G, Trimmer JS, Matthews G (2001) Compact myelin dictates the differential targeting of two sodium channel isoforms in the same axon. Neuron 30:91-104.

Boyle MET, Berglund EO, Murai KK, Weber L, Peles E, Ranscht B (2001) Contactin orchestrates assembly of the septate-like junctions at the paranode in myelinated peripheral nerve. Neuron 30:385-397.

Bronstein JM, Chen K, TiwariWoodruff S, Kornblum HI (2000) Developmental expression of OSP/claudin-11. J Neurosci Res 60:284-290.

Caldwell JH, Schaller KL, Lasher RS, Peles E, Levinson SR (2000) Sodium channel $\mathrm{Na}_{\mathrm{V}} 1.6$ is localized at nodes of Ranvier, dendrites, synapses. Proc Natl Acad Sci USA 97:5616-5620.

Dentinger MP, Barron KD, Csiza CK (1982) Ultrastructure of the central nervous system in a myelin deficient rat. J Neurocytol 11:671-691.

Dugandzija-Novakovic S, Koszowski AG, Levinson SR, Shrager P (1995) Clustering of $\mathrm{Na}^{+}$channels and node of Ranvier formation in remyelinating axons. J Neurosci 15:492-503.

Duncan ID, Hammang JP, Trapp BD (1987) Abnormal compact myelin in the myelin-deficient rat: absence of proteolipid protein correlates with a defect in the intraperiod line. Proc Natl Acad Sci USA 84:6287-6291.

Dupree JL, Girault JA, Popko B (1999) Axo-glial interactions regulate the localization of axonal paranodal proteins. J Cell Biol 147:1145-1151.

ffrench-Constant C, Miller RH, Kruse J, Schachner M, Raff MC (1986) Molecular specialization of astrocyte processes at nodes of Ranvier in rat optic nerve. J Cell Biol 102:844-852.

ffrench-Constant C, Raff MC (1986) The oligodendrocyte-type-2 astrocyte cell lineage is specialized for myelination. Nature 323:335-338.

Fjell J, Hjelmstrom P, Hormuzdiar W, Milenkovic M, Aglieco F, Tyrrell L, Dib-Haji S, Waxman SG, Black JA (2000) Localization of the tetrodotoxin-resistant sodium channel $\mathrm{NaN}$ in nociceptors. NeuroReport 11:199-202.

Goldin AL (1999) Diversity of mammalian voltage-gated sodium channels. Ann NY Acad Sci 868:38-50.

Gow A, Southwood CM, Lazzarini RA (1998) Disrupted proteolipid protein trafficking results in oligodendrocyte apoptosis in an animal model of Pelizaeus-Merzbacher disease. J Cell Biol 140:925-934.

Gow A, Southwood CM, Li JS, Pariali M, Riordan GP, Brodie SE, Dania J, Branstein JM, Kachar B, Lazzarini RA (1999) CNS myelin and Sertoli cell tight junctions strands are absent in Osp/claudin-11 null mice. Cell 99:649-659.

Griffiths I, Klugmann M, Anderson T, Yool D, Thomson C, Schwab MH, Schneider A, Zimmermann F, McCulloch M, Nadon N, Nave KA (1998) Axonal swellings and degeneration in mice lacking the major proteolipid of myelin. Science 280:1610-1613.

Grinspan JB, Marchionni M, Reeves M, Coulaloglou M, Scherer SS (1996) Axonal interactions regulate Schwann cell apoptosis in developing peripheral nerve: neuregulin receptors and the role of neuregulins. J Neurosci 16:6107-6118.

Grinspan JB, Coulaloglou M, Beesley JS, Carpio D, Scherer SS (1998) Maturation-dependent apoptotic cell death of oligodendroglial cells in myelin-deficient rats. J Neurosci Res 54:623-634.

Hildebrand C, Waxman SG (1984) Postnatal differentiation of rat optic nerve fibers: electron microscopic observations on the development of nodes of Ranvier and axoglial relations. J Comp Neurol 224:25-37.

Kaplan MR, Meyer-Franke A, Lambert S, Bennett V, Duncan ID Levinson SR, Barres BA (1997) Induction of sodium channel clustering by oligodendrocytes. Nature 386:724-728.

Kaplan MR, Cho M-H, Ullian EM, Isom LL, Levinson SR, Barres BA (2001) Differential control of clustering of the sodium channels $\mathrm{Na}_{\mathrm{v}} 1.2$, $\mathrm{Na}_{\mathrm{v}} 1.6$ at developing CNS nodes of Ranvier. Neuron 40:105-119.

Lambert S, Davis JQ, Bennett V (1997) Morphogenesis of the node of Ranvier: co-clusters of ankyrin and ankyrin-binding integral proteins define early developmental intermediates. J Neurosci 17:7025-7036.

Langford LA, Coggeshall RE (1981) Unmyelinated axons in the posterior funiculi. Science 211:176-177.

Lee V, Wu HL, Schlaepfer WW (1982) Monoclonal antibodies recognized individual neurofilament triplet proteins. Proc Natl Acad Sci USA 79:6089-6092.

Lee VM-Y, Carden MJ, Schlaepfer WW, Trojanowski JQ (1987) Mono- 
clonal antibodies distinguish several differentially phosphorylated states of the two largest rat neurofilament subunits (NF-H and NF-M) and demonstrate their existence in the normal nervous system of adult rats. J Neurosci 7:3474-3488.

Lipsitz D, Goetz BD, Duncan ID (1998) Apoptotic glial cell death and kinetics in the spinal cord of the myelin-deficient rat. J Neurosci Res 51:497-507.

Morita K, Sasaki H, Fujimoto K, Furuse M, Tsukita S (1999) Claudin11/OSP-based tight junctions of myelin sheaths in brain and Sertoli cells in testis. J Cell Biol 145:579-588.

Nave K-A, Boespflug-Tanguy O (1996) Developmental defects of myelin formation: from X-linked mutations to human dysmyelinating diseases. Neuroscientist 2:33-43.

Noebels JL, Marcom PK, Jalilina-Tehrani MH (1991) Sodium channel density in hypomyelinated brain increased by myelin basic protein gene deletion. Nature 352:431-434.

Novakovic SD, Deerinck TJ, Levinson SR, Shrager P, Ellisman MH (1996) Clusters of axonal $\mathrm{Na}^{+}$channels adjacent to remyelinating Schwann cells. J Neurocytol 25:403-412.

Pedraza L, Owens GC, Green LAD, Salzer JL (1990) The myelinassociated glycoproteins: membrane disposition, evidence of a novel disulfide linkage between immunoglobulin-like domains, and posttranslational palmitylation. J Cell Biol 111:2651-2661.

Peles E, Salzer JL (2000) Molecular domains of myelinated fibers. Curr Opin Neurobiol 10:558-565.

Peles E, Nativ M, Campbell PL, Sakurai T, Martinez R, Lev S, Clary DO, Schilling J, Barnea G, Plowman GD, Grumet M, Schlessinger J (1995) The carbonic anhydrase domain of receptor tyrosine phosphatase $\beta$ is a functional ligand for the axonal cell recognition molecule contactin. Cell 82:251-260.

Peles E, Nativ M, Lustig M, Grumet M, Martinez R, Plowman GD, Schlessinger J (1997) Identification of a novel contactin-associated transmembrane receptor with multiple domains implicated in proteinprotein interactions. EMBO J 16:978-988.

Poliak S, Gollan L, Martinez R, Custer A, Einheber S, Salzer JL, Trimmer J, Shrager P, Peles E (1999) Caspr2, a new member of the neurexin superfamily is localized at the juxtaparanodes of myelinated axons and associates with $\mathrm{K}^{+}$channels. Neuron 24:1037-1047.

Poliak S, Gollan L, Salomon D, Berglund EO, Ranscht B, Peles E (2001) Localization of Caspr2 in myelinated nerves depends on axon-glia interactions, the generation of barriers along the axon. J Neurosci 21:7568-7575.

Popko B (2000) Myelin galactolipids Mediators of axon-glial interactions? Glia 29:149-153.

Rasband M, Trimmer JS, Schwarz TL, Levinson SR, Ellisman MH, Schachner M, Shrager P (1998) Potassium channel distribution, clustering, and function in remyelinating rat axons. J Neurosci 18:36-47.

Rasband MN, Peles E, Trimmer JS, Levinson SR, Lux SE, Shrager P (1999) Dependence of nodal sodium channel clustering on paranodal axoglial contact in the developing CNS. J Neurosci 19:7516-7528.
Rasband MN, Shrager P (2000) Ion channel sequestration in central nervous system axons J Physiol (Lond) 525:63-73.

Rasband MN, Trimmer JS (2001a) Developmental clustering of ion channels at and near the node of Ranvier. Dev Biol 236:5-16.

Rasband MN, Trimmer JS (2001b) Subunit composition and novel localization of $\mathrm{K}^{+}$channels in spinal cord. J Comp Neurol 429:166-176

Rios JC, MelandezVasquez CV, Einheber S, Lustig M, Grumet M, Hemperly J, Peles E, Salzer JL (2000) Contactin-associated protein (Caspr), contactin form a complex that is targeted to the paranodal junctions during myelination. J Neurosci 20:8354-8364.

Rosenbluth J (1981) Axoglial junctions in the mouse mutant shiverer. Brain Res 208:283-297.

Rosenbluth J (1987) Abnormal axoglial junctions in the myelin-deficient rat mutant. J Neurocytol 16:497-509.

Rosenbluth J (1995) Pathology of demyelinated and dysmyelinated axons. In: The axon (Waxman S, Kocsis J, and Stys P, eds), pp 391-411. New York: Oxford UP.

Schaller KL, Caldwell JH (2000) Developmental, regional expression of sodium channel isoform $\mathrm{NaCh} 6$ in the rat central nervous system. J Comp Neurol 420:84-97.

Struckhoff G, Przyrembel C, Bahr M, Gocht A (1997) Fate of developing astrocytes in the optic nerve of the myelin-deficient rat. J Comp Neurol 378:105-116.

Tait S, Gunn-Moore F, Collinson JM, Huang J, Lubetzki C, Pedraza L, Sherman DL, Colman DR, Brophy PJ (2000) An oligodendrocyte cell adhesion molecule at the site of assembly of the paranodal axo-glial junction. J Cell Biol 150:657-666.

Trimmer PA, Wunderlich RE (1990) Changes in astroglial scar formation in rat optic nerve as a function of development. J Comp Neurol 296:359-378.

Vabnick I, Messing A, Chiu SY, Levinson SR, Schachner M, Roder J, Li CM, Novakovic S, Shrager P (1997) Sodium channel distribution in axons of hypomyelinated and MAG null mutant mice. J Neurosci Res 50:321-336.

Wang H, Allen ML, Grigg JJ, Noebels JL, Tempel BL (1995) Hypomyelination alters $\mathrm{K}^{+}$channel expression in mouse mutants shiverer and Trembler. Neuron 15:1337-1347.

Weber P, Bartsch U, Rasband MN, Czaniera R, Lang Y, Bluethmann H, Margolis RU, Levinson SR, Shrager P, Montag D, Schachner M (1999) Mice deficient for tenascin-R display alterations of the extracellular matrix and decreased axonal conduction velocities in the CNS. J Neurosci 19:4245-4262.

Westenbroek RE, Merrick DK, Catterall WA (1989) Differential subcellular localization of the RI and RII $\mathrm{Na}^{+}$channel subtypes in central neurons. Neuron 3:695-704

Westenbroek RE, Noebels JL, Catterall WA (1992) Elevated expression of type II $\mathrm{Na}^{+}$channels in hypomyelinated axons of shiverer mouse brain. J Neurosci 12:2259-2267. 